\title{
Markets, Human Capital, and Inequality: Evidence from Rural China
}

By: Dwayne Benjamin, Loren Brandt, Paul Glewwe, and Guo Li

Working Paper Number 298

March 2000 


\title{
MARKetS, HumAn CAPITAL, AND INEQUALITY:
}

\section{EVIDENCE FROM RURAL CHINA}

\author{
Dwayne Benjamin \\ University of Toronto \\ Loren Brandt \\ University of Toronto \\ Paul Glewwe \\ University of Minnesota \\ Guo Li \\ World Bank \\ August, 1999 \\ This version: March, 2000
}

This is a revised version of a paper prepared for the IEA World Congress panel sessions on "Global Inequality: Where Are We and Where Are We Headed," Buenos Aires, August 23-27, 1999. We thank Richard Freeman and conference participants for comments. Benjamin and Brandt thank the SSHRC for financial support. 


\begin{abstract}
Market reforms are generally credited with the rapid growth enjoyed by China's rural sector. This growth has not been without some cost, however, as inequality has also increased. Estimates suggest that the Gini rose from less than 0.20 to over 0.40 during this period. In this paper we go behind these numbers to explore the nature and causes of this inequality. To begin, we find that a considerable share of rural inequality is driven by local differences in household incomes, as opposed to regional income differences, that have been the focus of the previous literature. We then examine inter-household income differentials at the village level, exploring the links between education, market development, nonagricultural employment, and household income. To address these questions, we draw on a recently collected data set from Northeast China, that was collected by two of the authors in collaboration with Chinese colleagues in Hebei and Liaoning provinces in 1995. For purposes of comparison, we also draw on the Chinese Health and Nutrition Survey. We find that indeed, increasing rates of return to education and unevenly developed non-agricultural business opportunities contribute to the high levels of inequality in the countryside. Of most interest, however, is the implication that simultaneous improvements in educational attainment and off-farm market-development would allow more households to share in the rapid growth in rural China.
\end{abstract}

JEL Classification: 015, D3, P00 


\section{Introduction}

Beginning in the 1980s, almost all of the socialist countries replaced their planned economies with economic systems that relied heavily on market forces to determine the production and allocation of goods and services. This transformation has affected the lives of nearly 2 billion people. Historically, the two main arguments in favour of planned economies were that they are more productive in the long run (because they avoided the inherent instability of market forces, and were able to mobilize more resources for investment than a decentralized system), and that they provide a more equitable distribution of income. The experience of both socialist and market economies in the $20^{\text {th }}$ century decisively rejects the first argument; it would be hard to find observers of almost any persuasion who claim that planned economies are more productive or more efficient than market economies. Yet the second argument may well be valid; planned economies may indeed be more equitable than market economies. This raises the possibility that some societies may wish to retain at least some of the policies of planned economies, despite their inefficiencies, to maintain a more equitable distribution of income. Consequently, for countries that abandoned planning in favour of the market an important policy issue is the extent to which this policy shift has increased inequality.

This paper examines inequality in China, the first socialist economy to begin the transformation from a planned to a market economy, using data collected in rural areas of Northeast China in 1995. As explained below, official statistics from China show a substantial increase in inequality in rural areas since the introduction of the market economy, yet there is very little evidence on the causes of this increased inequality and the mechanisms through which it increased. This paper uses an unusually rich data set to examine these deeper questions.

We begin by reviewing a number of conceptual issues linking the transition from planned to market-based determination of incomes to inequality. In this discussion we highlight the potentially crucial roles that human capital, such as formal education, and market institutions might play in affecting the degree of inequality associated with transition. After providing a brief review of the existing literature 
on inequality in China, we turn to our own empirical explorations. Rather than trying to summarize the sources of inequality in a country as vast as China, we focus on households in a 6 counties in Liaoning and Hebei. What we sacrifice in breadth of sample is more than made-up in the detailed household-level information.

We confirm some of the findings of the existing literature, namely that non-agricultural income has been the driving force in increases in inequality, and that the educated have been most able to take advantage of economic transition. However, we also show that the existing literature has underemphasized a number of important points. First, most of the inequality we observe is within villages, not driven by differences in income levels across locations. This is especially true of the role of nonagricultural income. Second, the role of human capital is paramount in determining the evolution of inequality, especially in the way it interacts with unevenly developed local market opportunities that characterize economic transition. Third, differences in capital accumulation (savings) across households will contribute even more to inequality in the future. Finally, on a practical note, several important data, measurement, and econometric issues associated with evaluating inequality have been ignored, which underlines the importance of survey design and data collection in future research on inequality in transition economies. Measuring the consequences of economic transition requires household surveys that can keep up with the changing nature of household economic activity. This point has been made before by Ravallion and Chen (1996), and our results confirm their insight.

\title{
II. Economic Transition and Inequality
}

\author{
A. Institutional Background: Transition and China's Rural Reform \\ The reform of China's rural sector dates from the late 1970s. The key to the reforms was \\ implementation of the Household Responsibility System (HRS), which marked the re-introduction of \\ family farming to China's agricultural sector after nearly twenty five years of collectivized agriculture. \\ Under HRS, households received land-use rights and residual income rights, in return for meeting tax and
}


obligatory sales quotas to the state. The land-use rights were typically distributed to households on an egalitarian basis, using allocation rules based on household size and demographic composition.

Ownership, however, remained vested in the village, or former collective, with a majority of villages electing to redistribute use rights to existing and newly formed households every 4-6 years. ${ }^{1}$ By 1982, 98 percent of Chinese rural households were producing under HRS. ${ }^{2}$

Simultaneously, price and marketing reforms were carried out that heralded a long-run decline in government planning of procurement and sales in the farm sector, and allowed for new entry in both input and output markets. ${ }^{3}$ By the early 1990s, procurement of agricultural products by the state commercial system had fallen to less than a third of total farm sales, down from over seventy percent in the late 1970s. Restrictions on household sideline activities in agriculture were also relaxed. Combined, these reforms increased the returns to a household's labor in the farm sector, and in the process sparked an enormous boom in agriculture growth. Between 1978-84, agricultural output grew 7.7 percent per year, or two and a half times the rate between $1952-78 .^{4}$

According to Ho (1994), the incentive effects of HRS had an unintended consequence of making between 25-30 percent of the rural labor force redundant in farming. The policy imperative of finding ways to absorb this surplus labor, fiscal decentralization, and a relaxation of restrictions on entry into industry spurred the development and growth of local enterprise under local government initiative. ${ }^{5}$ Between 1980 and 1995, output in township and village enterprises (TVEs) grew at an annual rate of nearly $18 \%$, or nearly twice that in the state sector, while employment increased over the same period from 30 million to 128.6 million. ${ }^{6}$ By 1995 , output by these firms constituted a quarter of total industrial

\footnotetext{
${ }^{1}$ For an extended discussion of the allocation of land rights, see Turner, Brandt and Rozelle (1999).

2 See Justin Lin (1994)

${ }^{3}$ See Sicular (1995), and Park and Rozelle (1998).

${ }^{4}$ Justin Lin (1992), citing Ministry of Agriculture estimates.

${ }^{5}$ See Byrd and Gelb (1990) and Naughton (1995).

${ }^{6}$ State Statistical Bureau (1998).
} 
output. Beginning in the mid-1990s, many of these firms were privatized, and the growth of privately owned enterprises in China's rural sector accelerated under a less discriminatory regime.

Finally, long-standing restrictions on mobility and migration from rural-to-urban and rural-torural areas were gradually relaxed beginning in the mid-1980s. ${ }^{7}$ Estimates differ, but one commonly cited estimate (Zhao (1999)) puts the number of migrants in China's urban areas at over 50 million. Much of this migration appears to be temporary, with a high percentage of the migrants ultimately returning to the countryside. Through their effect on wage earnings and remittances, these trends have potentially important implications for household behavior and the distribution of income.

In summary, the reforms of the 1980s and 1990s yielded two main changes in the way that households earn a living. First, the market - however imperfectly developed - replaced egalitarianmotivated, administrative "assignment" of income to households. Second, the reforms contributed to rapid increases in agricultural productivity, and the emergence of non-agricultural sources of income: economic development, in short. As we proceed, we will try to separate the impact of these two features of economic transition on income inequality, conceptually if not empirically.

\section{B. Transition and Inequality}

Even if every Chinese family got richer after the reforms, it is difficult to imagine inequality falling with a move to market-based income determination. In fact, official statistics show that income inequality in rural China increased significantly the last decade and a half. Results based on China's (annual) Rural Household Survey, show that the Gini coefficient increased from 0.21 in 1978 to 0.32 in 1994. ${ }^{8}$ Khan and Riskin (1998) report results based on data collected in a nationally representative survey for 1988 and 1995, using standard international definitions for household income. They suggest even higher levels of inequality, but confirm the rising trend: The Gini increased from 0.34 in 1988 to 0.42 in

\footnotetext{
${ }^{7}$ See the collection of papers edited by Lorraine West and Yaohui Zhao (1999).

${ }^{8}$ Ministry of Agriculture (1994)
} 
1995.

So inequality went up, but this tells us very little about why inequality rose, and leaves important questions unanswered. For example, is the increase transitory or permanent? Are the "losers" in transition likely to fall further behind as the economy grows and becomes more market-oriented? How much of the inequality is the consequence of markets per se, as opposed to a product of the accompanying growth and economic development? How much of the inequality is due to "market" based policies, and how much is due to remaining vestiges of socialist organization? How important are regional or sectoral aspects of the income distribution? Are there any obvious government policies that can lessen some of the diverging trends? Is the rising inequality - regional or otherwise- a threat to the political sustainability of reforms? Clearly, we cannot address all of these questions. Nevertheless, it is worth spending a short time tracing the economic avenues by which transition can increase inequality. We do this with a simple model that helps identify the key relationships that we want to explore in addressing these questions.

Imagine an economy with two villages $A$ and $B$, with $N_{A}$ and $N_{B}$ people. The distribution of income can be described by:

$$
F\left(y_{1 A}, y_{2 A}, \ldots, y_{N_{A} A}, y_{1 B}, y_{2 B}, \ldots y_{N_{B} B}\right) \equiv F(y)
$$

where $y_{h v}$ is household $h$ 's income in village $v$, and $y$ denotes the vector of everyone's income. In the most general framework, household income will depend on household endowments, $x$, and local economic conditions, including institutions, $I$, that determine how endowments convert to income:

$$
y_{h v}=g\left(x ; I_{v}\right)
$$

The function $g(\bullet)$ summarizes the mapping between endowments, village conditions, and household income. Perhaps the simplest form this function can take is that under a perfect markets model:

$$
y_{h v}=w_{v}^{M} \cdot x
$$

where endowments of villagers are valued at common village market prices, $w_{v}^{M}$, and households earn the 
full value of their endowments. We can take this model one step further by having factor prices equal across the two villages, in which case income inequality is driven entirely by the inequality of factor endowments. In this framework we can also calculate how much of the total inequality is due to differences in endowments between the villages. ${ }^{9}$

We can think of economic transition as a movement from a function $g\left(x ; I_{v}\right)$ with plannedeconomy (and collectivist) institutions, $I_{v}^{C}$, to a perfect markets-based set of institutions, $I_{v}^{M} \cdot{ }^{10}$ While no simple model is likely to hold during the transition period, we can imagine the changes in inequality that result from the movement from a collectivist economy with one set of prices, to a market economy with another set of prices.

For simplicity, we begin by ignoring any changes in "endowments" that result from transition. ${ }^{11}$ In a rural economy (under collectivization), the key factors of production are: land, labour, human capital (education), physical capital, political connections, and good luck. Under collectivization, land was collectively owned, and implicitly equally distributed. This is also true under the current transition, where land use-rights are distributed to households on an essentially constant per-capita basis. Per-capita labour is similarly distributed, then as now; the distribution of human capital is less clear. Physical capital, being collectively owned, was more equally distributed under collectivization. Political connections were not equally distributed, nor was good luck (fortune).

Under collectivization, household incomes were determined at the brigade (and team) level.

9 This is the "ecological" model of inequality described by Riskin (1994), whereby Chinese inequality is driven by differences in geographic endowments. The contrasting model (or emphasis) is provided by the "socioeconomic" model, described by Riskin, which emphasizes local institutions.

${ }^{10}$ This is a simplification: markets were not totally absent in the collectivist period, and in the market-based economy, there remain restrictions on price-setting behavior.

${ }^{11}$ Of course, endowments are likely to change with transition as well. Some reshuffling of endowments like land (or other entitlements) may occur as a direct consequence of government policy. As well, individuals will respond to the changed economy by acquiring factors of production, like human or physical capital. Our simplification is really a glossing over of the fact that there are few true "endowments" that correspond to economist's usual theoretical notion. 
Factor prices (work points) were set so that returns were relatively constant across agricultural tasks. Similarly, household incomes were adjusted on the basis of the number of dependents ("to each according to his needs."). The returns to human capital were further depressed by restricting the ability of households to engage in non-agricultural activities, where returns to education are typically highest. A simple representation of this institutional setting is: $y_{h v}=g\left(x ; I_{v}^{C}\right)=w_{v}^{c}{ }^{\prime} x+\gamma^{\prime} z$, where $w_{v}^{C}$ is the vector of endowment prices under collectivization, and ( is the return to non-productive characteristics, $z$ (needs).

Thus, we expect a highly egalitarian distribution of village income, with village-level income inequality deriving only perhaps from differences in household misfortune, such as the illness of household members, or political connections. Under this institutional framework, it thus seems reasonable to view the primary source of inequality in the rural economy as deriving from across-village differences in endowments.

How might the distribution of income change with a movement to market pricing of endowments? ${ }^{12}$ Since land is still (fairly) equitably distributed under the Household Responsibility System, that will not likely be a source of changes in inequality. Similarly, the distribution of labour remains essentially equal among households. The main changes will occur in returns to human capital, returns to physical capital, and the return to household fortune. While they do not belong directly in a market economy, it is also likely that political connections will help determine relative success.

There are at least a couple of dimensions in which the returns to human capital might increase. First, under the HRS, better farmers can retain their surpluses, and so the implicit return to human capital in farming will rise. If this human capital is unequally distributed, we expect an increase in overall inequality. Of course, given the constraints on farm size, there are limits to how much inequality can be generated by differences in farming ability. Much more important, with reform restrictions on household

\footnotetext{
${ }^{12}$ For an excellent description of the impact of transition on "social differentiation" (inequality), applied in a comparative perspective to China and Vietnam, see Van Luong and Unger (1998).
} 
engagement in non-agricultural activities were gradually relaxed. It is here where we expect the returns to skill to matter most. Skilled individuals can set up their own businesses, or work for others in nonagricultural pursuits, such as TVE's. To the extent that these opportunities are unequally distributed across households, because of inequality of human capital, connections, or good fortune, then we expect to see an increase in village inequality. With fixed distributions of endowments, this inequality will be reflected in changes in the factor prices. Applied to the entire rural economy, we expect to see an increase in inequality both between and within villages. Some villages, because of advantageous locations, might see greater non-agricultural development.

Of course, transition concerns the entire process of change, not the instantaneous movement to a new set of institutions. One prediction of a more gradual movement to a market-based, less agricultural economy is the emergence of a sector-based "Kuznets curve." Overall inequality will be higher, as some regions' average incomes rise through the taking advantage of the new non-agricultural opportunities. This might also be true within-villages, as some households move into these more lucrative opportunities sooner than others. Only after a period of time, through the effect of migration, trade, or other factor mobility, will income differences between regions and across households be diminished.

The possibility of spatially uneven rural development, especially driven by the growth of township and village enterprises is prominent in the literature. ${ }^{13}$ Through the early 1990s, TVEs were the most rapidly growing segment of the industrial sector, and by 1997 absorbed more than 125 million workers. ${ }^{14}$ Conventional wisdom, represented for example by Rozelle (1994), suggests that the growing concentration of these enterprises in richer parts of China led to widening inter-regional differences. Fiscal decentralization, restrictions on inter-regional factor mobility and protectionism tended to magnify these gaps.

${ }^{13}$ See Hare (1994), Khan and Riskin (1998), Guojia Jiwei (1995), Knight and Song (1993) and Knight and $\operatorname{Li}(1997)$.

${ }^{14}$ Statistical Yearbook of China (1998) 
There are a number of shortcomings to this work. First, some of the analysis, such as Howes and Hussain (1994), and Rozelle (1994), is carried out using per capita welfare measures at the aggregate level, (e.g. the village, township, county, or provincial level). This has two effects. On the one hand, it effectively underestimates inequality because it ignores any differences arising from differences among households within these administrative units. In other words, it focuses solely on inter-local differences. At the same time, conclusions drawn from these data about the contribution of various factors, e.g. TVEs, to overall inequality are valid only insofar as most of the inequality is arising from differences in mean incomes between these units.

Still, the exercise can be informative about trends in inequality. We conduct this exercise ourselves in Figure 1. Here we calculate the country-wide (rural) Gini coefficient, assuming that everyone in a province has the same income. This eliminates within-province inequality by construction, so that all inequality is due to regional income differences. The figure shows similar trends for inequality of both income and consumption. The Gini rises from around 0.10 in 1980 (at the beginning of the reforms) to 0.15 in 1997 . This shows that Chinese inequality rose by 50 percent because of widening regional disparities. However, if we take other measures of total rural inequality reported earlier as benchmarks, then at most one half $(0.10 / 0.21$ and $0.15 / 0.32)$ of national inequality can be attributed to income differences between provinces. This fraction is even smaller if we use benchmarks based on most other recent household surveys, where the current Gini's are over 0.40 . Thus, at least half, and probably more, of current inequality is due to income differences among "neighbouring" households.

Our back-of-the-envelope exercise yields similar results to more formal studies of spatial inequality. For example, Tsui (1991) confirms our estimates of the broad trends in provincial income inequality for the earliest part of our sample. Regarding the contribution of cross-province inequality to the total, Hussain, Lanjouw, and Stern (1994) in a sample drawn from 10 provinces, find that only 15 percent of inequality of household income was due to provincial income differences. Cheng (1996) employs data from 5 provinces, and finds under 40 percent of the inequality due to cross-province income 
differences. Clearly, one expects that such results will be sensitive to the provinces examined, and the degree of measurement error in the household data. We pursue these question later, with our own empirical explorations. The main point we make here is that uneven spatial economic development, due to TVE's or other types of industrialization, only yields a half-story, at best, about links between transition and inequality. We must look at individual provinces and villages in order to appreciate more fully the impact of institutional change.

Other studies, e.g. Hare (1994), Kahn and Riskin (1998), used household-level data to explore the possible impact of uneven rural development on income inequality. These papers focus on the changing composition of rural household income (possibly due to TVE's). While these studies do not separate the spatial and non-spatial dimensions, they verify the important contribution of income from non-agricultural sources to inequality. But, with the exception of Hare (1994), no attention is given to why income from alternative sources may differ at the household level. This is extremely important if certain kinds of income are more disequalizing that others, and for the design of policies that may help reduce inequality. Also, interpretation is difficult when income from alternative income sources is lumped together, e.g. income from off-farm wages is combined with that from family-run businesses. Insofar as these sources of income are less than perfectly correlated with each other, grouping them together may hide important aspects of emerging inequality and their links to household attributes and the external economic environment with which these households interact.

While it is simple to think of transition as a quick movement from collective to market-based factor prices, it is also misleading. Markets are likely to be imperfect for some time, so the function mapping endowments to incomes is likely much messier than suggested by the market clearing model. Instead of valuing household endowments at market factor prices, they will be valued at shadow prices:

$$
y_{h v}=\bar{w}_{h v}{ }^{\prime} x
$$

where $\bar{w}_{h v}$ is the vector of shadow factor prices. Shadow prices can depend on both village and 
individual household characteristics, and may be written as:

$$
\bar{w}_{h v}=h\left(x, I^{T}, w, \varepsilon\right)
$$

depending on the distribution of endowments, local institutions, market prices, and other factors. Some aspects of transition might make inequality worse than the case in which the movement to a new market clearing outcome was instantaneous. Shadow prices might also be unequally distributed in a village, so that those with more endowments have their favourable position compounded by advantageous prices. This will especially be the case if there is quantity rationing in the various factor markets, so that those households with poor endowments cannot get "full value" for their limited endowments of labour and land.

The most interesting possibility concerns the role of human capital. Not only might education be the key to accessing scarce non-agricultural opportunities, but it may play an independent role in helping households cope with dramatic economic change. Economic transition is almost certainly a process where information about income earning opportunities, and how best to take advantage of them, is highly imperfect. The more educated, either directly because of their education, or simply as a reflection of innate ability, may thrive in such an environment. This possibility was raised, most notably by Schultz (1975), but more recently by Rosenzweig (1995) in the context of development, and Orazem and Vodopivec (1995) in the context of transition. Indeed, given the nature of transition in China, the distinction between the pure effects of institutional transition and economic development are fuzzy, at best. Combined, we expect the distribution of human capital to interact with the extent of new economic opportunities in complicated ways that imply high returns to education, and increased inequality. On a related note, political connections can be viewed as a special kind of human capital, especially if there is political rationing of the economic opportunities themselves, or of the information about them.

At this point, we know very little about how returns to human capital in China's rural sector are evolving. Several recent studies, however, provide some preliminary estimates. First, in contrast to the 
pre-reform period, the return to education in agriculture during reform is positive. Li and Zhang (1998), using household level data for Sichuan for 1990, find a return of about 3 percent to average years of schooling of family members in agriculture. Using the educational level of the household head, they find a similar return, with the return to education of those individuals schooled during the Cultural Revolution slightly lower. They do not find a significant return to schooling in the pre-reform period, consistent with the highly redistributive tendencies of the collective. Dennis Yang (1997) finds a similar return to education during the reform period, but argues that most of it is coming through its effect on the household's managerial capabilities as opposed to any effect it may have on household members' ability to perform routine tasks in agriculture. He finds a slightly lower return to schooling in off-farm wages. ${ }^{15}$ More recently, An and Yang (1998) analyzed the returns to schooling in total household operations and that to agriculture and non-agriculture activity separately. They find a much higher return to total household activity, and suggest that as much as half of the effect of human capital on earnings is coming through its effect on the allocative decisions households are making across sectors. While these results are suggestive, no linkages to inequality are explored.

Finally, the role of physical capital is likely to be very different in a transition economy than in either a purely collective or purely market based one. Under collectivization, household accumulation of capital was severely restricted. With economic reforms, successful households can accumulate physical capital. With perfect capital markets, this will generate inequality on its own, to the extent that economic success is unequally distributed. However, if capital markets are imperfect, then the effect on inequality will be more severe. Unequal capital holdings might interact with unequal (or limited) access to capital, further compounding income inequality, especially to the extent that capital is a necessary input in the operation of non-agricultural (or even agricultural) businesses. We expect, therefore, the accumulation of

\footnotetext{
15 The low return in the wage sector may reflect differences in the wage determination between workers who are assigned to jobs (non-market group) versus those who find jobs themselves (market group). Gregory and Min (1995) find a significant return to schooling for the latter group, but no return for the non-market job-holders. They are not, however, able to explain the assignment of workers to these sectors.
} 
capital to combine with the distribution of other factors (especially education) to generate even more inequality of income from non-agricultural sources, and income inequality over all.

In summary, we can think of transition as the movement from administered to market-determined prices of factor endowments. In this way we can speculate on the likely consequences of transition on incomes and inequality. However, transition is more complicated than that. Imperfect development of factor markets is likely to combine with the changing distribution of endowments to worsen inequality.

\section{The Data}

We use two sources of household level data. Our main data set is the 1995 North and Northeast China Living Standards Survey (NNCLSS). We also use the China Health and Nutrition Survey (CHNS) for comparison.

\section{A. The NNCLSS: Sampling Frame}

This survey was carried out by the authors and Chinese colleagues in 1995 and extends to 780 households in 6 counties, 18 townships, and 30 villages in Hebei and Liaoning provinces (NorthNortheast China). The survey provides detailed household level information on income, expenditure (disaggregated for farm and non-farm activity), labour supply and farm management. The basic structure of the survey was based on the World Bank's Living Standards Measurement Survey, described in more detail by Glewwe and Grosh (1998).

The six counties were not selected randomly, but chosen to correspond to the site of an intensive household-level investigation carried out by Japanese investigators in 1936 and 1937. Five villages in each county were selected, one of which had been fully enumerated in the 1930s. The other four villages in the county, including one from the same township as the administrative capital of the survey; one located in the same township as the village surveyed in the 1930s; and two drawn from a third township, were selected to try to obtain as representative cross-section in each county as possible. 130 households were surveyed in each county: Fifty from the village surveyed in the 1930s, and twenty from each of the 
remaining four villages. Households were chosen randomly using the most recent village registry.

\section{B. The CHNS: Sampling Frame}

We also use data collected for rural households as part of the China Health and Nutrition Survey. While this survey is longitudinal, we only make use of the single cross-section for 1993 (from the survey carried out in 1994). A detailed description of these data (as well as the data itself) can be obtained at the website. ${ }^{16}$ The CHNS data include the provinces of Lioaning, Shandong, Jiangsu, Henan, Hubei, Hunan, Guangxi, and Guizhou, and provides a more nationally representative survey than our 1995 data. Missing, however, are provinces from China's southeastern coast (Zhejiang, Fujian, and Guangdong). In each of the eight provinces, three rural villages in four counties, for a total of 96 villages were sampled. Total sample size (of rural households) is around 1800, with approximately 20 households sampled per village.

In Figure 2 we present a map that shows the locations of the provinces sampled in the two surveys. Only Liaoning is sampled in both surveys. On the same map, we show the per capita rural income levels in 1994. Most of the provinces have income levels in the middle two categories: 900-100; and 1100-1400 Yuan per year. Liaoning is in the richest category. So, this sample will likely understate the degree of heterogeneity in China as a whole, as it excludes both the very poorest, as well as the richest provinces. That said, it is difficult to imagine coming to any conclusions, statistical or anecdotal, that could generalize across all of China. Our conclusions will never be intended as China-wide statements. That said, each of the sample provinces has a population greater than most developing countries!

\section{Empirical Results}

\section{A. Descriptive Statistics}

Table 1 provides descriptive statistics for the various sorts of income earned by households in our 1995 sample. For each source of income, we report unconditional means, including in our calculations

16 http://www.cpc.unc.edu/projects/china/china_home.html 
any zeroes and negative values as well as the proportion of households with non-missing observations on each source of income. As a measure of income dispersion, we show the Gini coefficient, calculated only over the observations with positive values. The numbers are calculated using all 778 households with complete income and expenditure information, including several possibly "big" outliers.

Average household, and household per capita, income in our sample are 13,071 and 3,510 RMB, respectively. These estimates are higher than those reported on the basis of the SSB's Rural Household Survey. Only $10 \%$ of this difference can be attributed to the inclusion of the imputed value of capital services. Other reasons for these differences are probably driven by differences in survey methodology. Our LSMS style survey is more comprehensive in its enumeration of income sources, and includes several built-in consistency checks with which to "double-check" estimated income. Turning to consumption, average household expenditure is considerably lower than income, but still at a level that suggests that previous estimates of living standards have understated household incomes. At 1994 exchange rates, our estimate implies a per capita income of US\$400. Purchasing power parity calculations suggest per capita income three times higher. ${ }^{17}$ The difference between income and expenditure also implies significant household savings, a point to which we return later.

Farming is the most important economic activity for these households: it accounts for nearly half of total income, and all but two percent of the households have positive farm income. In turn, nearly three-quarters of farm income comes from cropping income (mostly corn in Hebei, and rice and corn in Liaoning), with the remainder from sidelines such as vegetable gardens and greenhouses. Next important to farming, family-run businesses are the source of slightly more than twenty percent of total household income. ${ }^{18}$ Nearly a third of all households, or 247 households, are involved in a total of 274 nonagriculture businesses of some kind, with ten percent of the households involved in more than one

\footnotetext{
${ }^{17}$ On this point, see Lardy (1994).

${ }^{18}$ Income from family-run businesses represents both profits plus the implicit returns to family labor. We do not try to break up these two components.
} 
enterprise. A third of the enterprises are in commerce, with fifteen percent in construction and transportation. On average, 2.2 individuals work in these enterprises, with the average enterprise having been in operation for almost five and a half years. Wage income is the source of about $15 \%$ of total income, with three-quarters of that coming from male wages. Forty percent of the households report income from this source. ${ }^{19}$ The remainder of income comes from animal husbandry and an "other" category, which includes such things as interest income, remittances, pension income, etc.

The Gini coefficient for household income for the entire sample is .40, and marginally lower for per-capita household income. Our estimate is similar to that obtained by Khan and Riskin (1998) in a nationally representative survey that used comparable measures of income. Among the sources of income, income from wages and farm income are the most equitably distributed. The latter is largely a product of a fairly egalitarian distribution of land at the village level. The most unequally distributed items, on the other hand, are income from family-run business, animal husbandry, and our "other" category. This suggests that we look to these items in our analysis of the factors underlying the increase in inequality.

Finally, household expenditure, a potentially superior estimate of long-run living standards, is considerably more equally distributed than income, with a Gini for household expenditure of 0.28 . In Figure 3, we graph the kernel densities for these two measures, which reveals a much fatter upper tail for income. While some of this difference may be the usual product of measure error in income relative to consumption, it may also reflect genuine differences between income and consumption, and potentially important savings behaviour.

\section{B. Spatial Dimensions of Inequality}

Following on the issues raised in our discussion of Figure 1, we now explore how much of the

${ }^{19}$ Slightly more than a third (36.2 percent) of these jobs were in the villages in which these households lived; 43.1 percent were in either the county or township seat; and the remainder (20.7 percent) were in the cities. Most of these jobs households found on their own and were not "allocated" or "rationed". 
inequality in our sample is at the local level, as opposed to differences in average incomes across regions. For the pre-reform era, it is generally believed that most of the inequality was eliminated within localities, but not across regions. ${ }^{20}$ With reforms, we might expect inequality to increase within villages, as collectivist institutions eroded. However, we might also expect inequality to increase across regions as well, as some areas are in a better position to take advantage of non-agricultural and other opportunities arising as a product of market liberalization and reform. In the exercises below, we decompose inequality into that part due to differences between and within localities.

Table 2 reports decomposition estimates for a variety of measures of income and expenditure inequality, using a number of alternative definitions of "location" (village, county and province). Expenditure data are not provided for the CHNS data, and so we report results for income only for that sample. ${ }^{21}$ We take as our benchmark the Gini coefficient for income or expenditure. We also show the variance of logs and the Theil index. The decompositions are most easily done and explained using the variance of logs: the R-squared from a regression of log income on location dummies provides an estimate of the percentage of the variation in log per capita income explained by location. The remainder represents the percentage arising from within-location variation. We also report the decomposition for the Theil index, which has a similar interpretation, but is generally a preferred inequality index.

The results consistently show that most of the inequality is within, not between, whichever inequality index is chosen. This means that while differences in such factors as the level of rural industrial development, soil quality, nearness to urban centers, etc., affect mean incomes across localities, most of the inequality still comes from differences among households within these locations. For the NNCLSS, 25 to 30 percent of the variation in both income and expenditure comes from between-village differences, with even lower percentages arising from differences at the county or provincial level. The

\footnotetext{
${ }^{20}$ See Putterman (1993) and Vermeer (1982).

${ }^{21}$ The public-use version of the CHNS data set for 1993 does not provide an estimate for household income. We constructed a measure using the definitions of alternative income sources provided for the 1989 and 1991 data.
} 
CHNS data suggest a similar spatial pattern, despite the fact that the CHNS sampling frame was chosen to maximize differences in economic development across villages. The basic insight to be gained from these decompositions is that understanding inequality in rural China requires understanding income determination within villages.

\section{Inequality and Sources of Income}

Which income sources generate the most inequality? W e decompose income inequality by source using a straightforward method employed by Shorrocks (1982, and 1983). With $K$ sources of income, total income for household $i$ is given by $y_{i}=\sum_{k=1}^{K} y_{i k}$. The vector of economy wide household

incomes is given by $Y=Y_{1}+Y_{2}+\ldots+Y_{K}$, where $Y$ and $Y_{k}$ are vectors of household income of source $k$ for the whole economy. Average income is given by: $\bar{Y}=\bar{Y}_{1}+\bar{Y}_{2}+\ldots+\bar{Y}_{K}$. An increase in the mean income of source $k$ by 1 penny leads to an increase in the mean of total income by one penny. A first order estimate of the proportional increase in mean total income is given by:

$$
W_{k}=\frac{\mu_{k}}{\mu}
$$

where $W_{k}$ is the share of income source $k$ in total income (evaluated at the mean). So, a 1 percent increase in income source $k$ will increase average income by $W_{k}$ percent: The more important the income source is, the larger the increase in mean income will be.

To what extent does the same logic apply to measures of inequality? Does an increase in the dispersion of a $Y_{k}$ lead to an increases of inequality in direct proportion to its income share, $W_{k}$ ? Stated differently, under what conditions can we write: 


$$
I(Y)=\sum_{k=1}^{K} W_{k} I\left(Y_{k}\right)
$$

This simple decomposition can be done only if each source of income is perfectly correlated with total income, i.e., if everyone is a "clone" in terms of the structure of income, except in total income. ${ }^{22}$ In such a case, an increase in the inequality of income source $k$ will increase total income inequality in direct proportion to its share of total income.

However, to the extent that a particular type of income is earned by the rich, then an increase in inequality of this source of income is going to benefit the rich disproportionately, and so increase inequality in excess of its share of total income. On the other hand, an increase in inequality of income correlated with being poor will disproportionately benefit the poor, and so decrease inequality. Both the correlation of the source of income with total income, and its relative size will matter in any decomposition.

Shorrocks (1982) shows that under reasonable conditions, a decomposition of total inequality can be calculated, so that the fraction of total inequality deriving from $\mathrm{Y}_{\mathrm{k}}$ (for any inequality index) is:

$$
S_{k}=\frac{\operatorname{cov}\left(y_{k}, y\right)}{\operatorname{var}(y)}
$$

How can we interpret $S_{k}$ ? First, we can compare $S_{k}$ to zero. If $S_{k}$ is negative, increases in the inequality of income source $\mathrm{k}$ will actually reduce inequality because of the income source earned by (and distributed to) the poor. Second, we can compare $S_{k}$ to $W_{k}$. Since the rich tend to earn more income from all sources, increases in inequality of any income type increases overall income inequality. However, some sources may be relatively less disequalizing, and $W_{k}$ is a useful benchmark. If $S_{k}$ is greater than $W_{k}$, increases in the inequality of the distribution of $Y_{k}$ can be viewed as disproportionately increasing income inequality.

\footnotetext{
22 See Shorrocks (1983).
} 


\section{Estimation Issues}

The parameter of interest is $S_{k}$, which can be estimated as the coefficient from a regression of $y_{i k}$ on $y_{i}$ :

$$
y_{i k}=\alpha_{k}+\beta_{k} y_{i}+\varepsilon_{i k}
$$

The error term is worth noticing. For starters, we only have a sample (not the population) and must recognize that there is sampling error. More seriously, the error term may contain less benign components. Measurement error is the most significant possibility. Assume that each source of income is measured as follows:

$$
y_{i k}^{*}=y_{i k}+v_{i k}
$$

where $y_{i k}^{*}$ is the measured income, and $y_{i k}$ (as before) is the true value. Then, because measured $y_{i}$ is the sum of the various $y_{i k}$, there is a possibility of correlation between $y_{i}$ and $\varepsilon_{i k}$. This generates two possible biases. First, the plim of $\hat{\beta_{k}}$ may exceed $\beta_{k}$, because of the positive correlation between the common measurement error in components in $y_{i k}$ and $y_{i}$. For example, if a household overstates its non-farm income, this will spill over to the households total income. We will then overestimate the true association between non-farm income and total income. Second, we may instead get the usual attenuation bias of measurement error, in which case we will understate $\beta_{k}$.

This potential statistical problem can be addressed most easily by instrumental variable (IV) techniques. In our case we use per capita expenditure as an instrument for per capita income, because it is (mostly) measured independently of income. ${ }^{23}$ Even if the instrument is imperfect, this exercise allows

\footnotetext{
${ }^{23}$ We exclude the value of capital services from our instrument to minimize any mechanical overlap in the measurement of income and expenditure.
} 
us to explore the possible sensitivity of our conclusions to measurement error. Intuitively, we have two separate indicators for a household's position in the income distribution, and thus an alternative way to estimate the correlation between the various income sources and total income.

For the NNCLSS, we calculate the decompositions over two samples: the full sample, and one with the richest household dropped (this household had income over 200,000). This household is rich because of high non-farm business income, so the decompositions are sensitive to inclusion of this household. The results are reported in Table 3. For each source of income, we report three columns of numbers: 1) The share of the source of income in total income (the benchmark $W_{k}$ ); 2) The raw correlation coefficient (i.e., the OLS coefficient from the regression of income of type $k$ on total income); and, 3) The 2SLS estimate of this coefficient (i.e., the measurement error corrected correlation).

Looking at the full sample (the first three columns), most income sources contribute to inequality in approximate proportion to their share of income. Women's wages have a small negative (equalizing) contribution, while men's wages contribute less to inequality than their share. Crop income contributes much less than its share to inequality. Restrictions on land ownership, and the administrative allocation of land effectively place an upper bound on how much a household can earn from farming. In contrast, animal husbandry contributes more than its share, and non-farm family businesses contribute the most to inequality. These results suggest that it is income from these enterprises, not wages from TVE's, that is generating most of the inequality. The OLS and 2SLS coefficients do not differ significantly; however, the results are sensitive to the exclusion of the richest household. Dropping this household reduces the contribution of non-farm business income, but it does not change the overall story: In order to understand rural inequality we must understand non-agricultural income.

In the bottom panel of Table 3, we show comparable results using the CHNS. Even though the sampling frame is different, we find similar patterns to the NNCLSS. First, the income shares of each type are similar, even though the CHNS has some built-in gaps (such as the value of capital services). Crop income is the largest source of income, but contributes significantly less than its share to inequality. 
On the other hand, both animal husbandry and non-agricultural businesses contribute significantly more to inequality than their shares suggest. Our NNCLSS results do not seem to be an artifact of the sample.

In Table 4, we combine the previous two exercises, and explore how the contribution to inequality by income source varies over space. Our questions are: 1) How much of the contribution of non-agricultural income is driven by spatial differences in non-agricultural development; and 2) Does the contribution of non-agricultural income to inequality itself vary across villages? In columns 2 and 3, we show the coefficients that correspond to those reported in Table 3, except we include village fixed effects. Here, we see that adding village fixed effects does not change the conclusions drawn from Table 3: differential incomes from non-agricultural sources contribute significantly more to within-village inequality than is expected on the basis of their share in income. F-tests for village interaction terms show that the contribution of non-agricultural income to village inequality does vary across villages - perhaps due to differences in local institutions. However, when the village interactions are estimated by 2SLS, we do not find statistically significant differences across villages. Perhaps the OLS result is due to the higher fraction of measurement error at the village level, or alternatively, our results reflect the imprecision with which the instruments can predict differences in income between villagers.

\section{Household Income and Consumption}

We begin with an overview in Table 5 of the relationship between household endowments and total income and consumption. In the next section we look in more detail at how these productive characteristics, like land and human capital, affect the composition of income.

We specify the land variables as a combination of both the amount of land that the household has been allocated, and a dummy for whether or not the household has any land. It appears that land allocation is partially endogenous to the type of income earned. Rich households with sizeable nonagricultural enterprises do not receive allocated land, or elect to return it, so the coefficient on whether a household has land is negative. However, once we account for this heterogeneity, it appears that an 
increase in land holdings increases per capita income. Unless land were distributed disproportionately to the poor, this implies that an increase in land inequality leads to higher inequality (conditional on all other sources of income remaining unchanged). While not an endowment variable per se, if a household suffers an adverse production shock (measured in terms of the reduction in output from a normal year), its income falls significantly, but expenditures do not. One interpretation of this pattern of coefficients is that households are able to smooth their consumption relatively more than their income in response to bad luck. This suggests that the large gap between income and consumption may be related to savings (as opposed to only measurement error), and that these savings are used, at least partially, to smooth consumption.

Turning to the human capital variables, the coefficient on years of schooling implies a rate of return to schooling of around $6.6 \%$ for income, and $3.8 \%$ for expenditure. ${ }^{24}$ Unless there is a complicated covariance of the measurement error in income and consumption with education, the difference between the income and expenditure coefficients may reflect a correlation between savings rates and education. Technical training also has a significant rate of return, for both income and consumption, but apprentice training is insignificant. In order to see whether the rate of return to schooling varies across villages, we estimated an ANOVA, controlling for the same set of variables as above. An F-test for the interaction terms between education and the village dummies is significant at the $5 \%$ level. Later on, we explore in more detail how these differences across villages in the rate of return to human capital affect income inequality.

\section{E. Household Earnings Activities}

In Table 6 we explore the connections between education and the composition of income. Specifically, we report estimates of Probit equations for whether a household engages in animal

\footnotetext{
${ }^{24}$ These estimates are well in line with those reported in Psacharopolous (1985).
} 
husbandry, male wage labor, female wage labour, or non-agricultural farm businesses. The covariates are the same as in Table 5, including village fixed effects. The most important result is that education plays only a small role in determining what activities that households engage in. Those households raising animals tend to be slightly less educated, while those working off the farm for wages, especially wage labour are slightly more educated, with average household education being highly related to female participation in wage labour. Most interestingly, schooling does not seem to matter in determining whether a household is operating non-agricultural business. Having family members with either technical or apprentice training, on the other hand, increases the likelihood of having male members working off the farm, or the family engaged in non-agricultural businesses.

Table 7 shows the estimated "returns to schooling" for the various types of income. These regressions are estimated only over those households with positive earnings, so there may be selectivity biases on the various coefficients. Fixing this bias is impossible in the context of this paper. However, we can speculate about its likely consequences. Regarding the education coefficient, if there is a positive rate of return to schooling for a given source of income, and households are positively selected into an activity, then the OLS coefficients will be biased downwards (towards zero). These biases might not be large, given the absence of strong education effects on most activity in Table 6 , but we must note that the selection is not just into a specific activity, but also on whether a household has positive earnings (as opposed to losses) in that activity, which might be more strongly selected. For crop income and animal husbandry, we find only very small, but positive rates of return. Our estimates are consistent with those obtained in the previous literature. However, we estimate high rates of return in wage labour and nonagricultural income. Moreover, aggregating all types of non-crop income, we estimate a rate of return of about $10 \%$. This suggests that households have a rate of return to schooling, not just within each activity, but also in the construction of a portfolio of income types. The slightly higher return over all non-crop income might also reflect the fact that there is less selection bias in this equation, since fewer households are excluded. In summary, we find high rates of return to schooling in non-agricultural pursuits, though 
entrance into these activities is less related to education.

\section{F. Savings and Capital Accumulation}

In most empirical studies of inequality, measurement considerations dominate the choice between income and consumption (expenditures) as the measure of living standards. On these grounds, we usually prefer expenditures, since they tend to be better measured in developing countries. Furthermore, long run living standards are probably best reflected in consumption levels, as even accurately measured income may contain a significant transitory component. Our intention was to follow conventional practice, and draw most of our conclusions from the expenditure results. However, the divergence between income and consumption may reflect more than measurement error and transitory income shocks. As this is an economy in transition, households may not have settled into long run consumption patterns. In particular, high income households may be re-investing (saving) a considerable portion of their income, possibly in response to poorly developed external credit markets. In this case, we understate the differences in longrun living standards between households if we focus on consumption alone. Current income may be disproportionately related to future income (and consumption) through current savings. Essentially, savings is a mechanism by which "luck" and economic success will be compounded in a transition economy, even more than that implied by equilibrium models, suggested (for example) by Deaton and Paxson (1994) for Taiwan. We explore this possibility in detail.

As we previously pointed out, there is a considerable gap between household income and expenditures. For any individual household, this is not surprising given the degree of measurement error in household surveys. While it is tempting to interpret the difference between income and consumption as savings, the difference ("savings") may be mostly noise. More surprising, however, is the extraordinary level of implied savings across the whole sample. Evaluated at the median, household income (excluding capital services) is 9,352 versus 6,449 in expenditures, implying household savings of 2,903-a savings rate of 31 percent! Usually, reporting-error leads to higher levels of expenditure than income (which is 
under-reported), and negative "savings." We thus consider the possibility that some of this gap is genuine savings.

Our objective in this section is quite limited. We wish to evaluate whether, in fact, there appears to be savings "signal" in the difference between income and consumption, and thus that savings rates may be genuinely high. We already saw indirect evidence of savings in Table 5, where we noted the differential response of income and consumption to an agricultural production shock. This was consistent with savings being used for consumption smoothing (self-insurance). With imperfect markets and diminished redistributive institutions, and presumably riskier income streams, it is plausible that households now engage in more precautionary savings.

Our main cross-check is to evaluate the relationship between contemporaneous savings and the estimated stock of household wealth, beginning with some "back-of-the envelope" calculations. We construct estimates of the total investment by households in the accumulation of physical and financial assets. Financial assets consist of deposits in financial institutions, cash on hand, and net borrowing through formal and informal lending. We have year-end figures for each of these. We also have detailed data on durable goods expenditure, both that for household use, e.g. housing stock, and that used in agriculture and non-agriculture business activities. For these assets, we know the year purchased and the price paid. Almost all of this asset accumulation occurred in the 1980s and 1990s. In principal, total investment in asset accumulation should equal the sum of household savings over this period. These totals should not be confused with (but are related to) estimated net wealth, the current value of these assets. The difference between the two is depreciation and the effect of inflation on the value of these assets. Average total accumulated investment in productive and non-productive assets equals 25,856 yuan, and the median is 14,500 , or almost 1.5 times estimated median income. Out of this total investment, forty percent represents the fixed investment in agriculture and non-agriculture activity. Given the significant increases in nominal incomes between 1980 and 1995, it takes savings levels on the order of $30 \%$ in order to generate the estimated level of wealth! Given the rapid development of family 
enterprises and imperfect or nonexistent capital markets, such levels of savings might be necessary.

A more formal exploration is presented in Table 8. Define the "rate of savings," $r_{S}$, as:

$$
\ln \left(\frac{\text { income }}{\text { expenditures }}\right)=\ln (p c y)-\ln (p c x) \equiv r_{S}
$$

In column (I), we show the results of regressing $r_{S}$ on the same set of explanatory variables as Tables 7. First note that the savings rate is positively related to the level of schooling. Perhaps more educated households have lower discount rates; perhaps they have better investment opportunities; or possibly they are better decision makers. Second, we confirm that adverse production shocks reduce savings.

In columns II and III, we link assets to income. While we expect the two variables are positively related, the more interesting question is whether the elasticity is greater than one. If so, it suggests that wealth increases more than proportionately with income, i.e., that wealth is highly "disequalizing" or associated with high incomes. This suggests that not only is wealth unequally distributed (its Gini coefficient is 0.58 ), but that high income households have a disproportionate share of wealth. In column II we report OLS estimates, while in column III we report 2SLS estimates, where we try to correct for measurement in $\ln (\mathrm{pcy})$ using $\ln (\mathrm{pcx})$ as an instrument (like we did in tables 3 and 4). The OLS and 2SLS results are sufficiently different to lead to suspicion of measurement error bias. Focussing on the 2SLS results, the estimated elasticity is 1.5 and significantly higher than 1.0 , suggesting that if these assets yield future income, it will accrue to higher income earners, and further increase inequality.

In columns IV-VI we try to see whether there is any significant relationship between the "savings rate," and accumulated wealth. In column (IV), we estimate the "reduced form", observing that assets are highly related to the same variables as the "savings rate," most notably education and the production shock. In the next two columns, we estimate the "structural" asset equation by OLS and 2SLS, instrumenting the savings rate for measurement error (since we know that the difference between income and expenditure will be mostly noise). We use the indicator of the degree of production shock, farm size, 
and whether there are young children or teenagers in the household as instruments for the savings rate. We thus assume that these instruments affect assets only through the savings rate. We use overidentification tests to confirm the internal consistency of the instruments, and also show that empirically there is no evidence of a correlation between the identifying instruments and the error term of the asset equation. The results in Column VI suggest that the rate of "savings" is significantly, positively related to the level of accumulated assets, with an elasticity of almost one, which suggests a proportional relationship between the savings rate and the level of wealth.

All of this evidence suggests that there is genuinely high savings by these households. This fact needs to be taken into account in any picture of inequality in the transition to a market economy. Given the significant rate of savings, especially by high income households, we might expect the level of inequality to be even higher in the future. Our results also suggest that the role of imperfectly developed capital markets may be greater than previously believed, not just for economic efficiency, but also for income inequality.

\section{G. Overview of Village-level Inequality}

In this final section, we summarize some of the key determinants of inequality within villages, focussing on possible inter-linkages between the distribution of human capital and market development. While we use regressions to conduct this summary exercise, we are especially cautious in interpreting the coefficients causally: almost certainly these village characteristics evolved simultaneously. Instead, the regression coefficients should be treated as slightly sophisticated tabulations. The dependent variable is the Gini coefficient of village inequality, where the village Gini's range from under 0.2 to over 0.5 , with most lying on either side of 0.3 . Our focus is on how the distribution of education interacts with market development. Before turning to the results, it is first worth asking in what dimensions educational attainment varies across the households within the sample.

Educational attainment increased significantly with the expansion in the basic education system 
through much of the first three decades of the PRC. ${ }^{25}$ Both literacy and average years of schooling increased, while differences between males and females narrowed considerably with each successive cohort. ${ }^{26}$ There is considerable debate over the impact of the restructuring of the education system in the post-Mao era and the post-1978 economic reforms on educational attainment in rural China. On the one hand, the re-introduction of family farming with the HRS and the rapid development of off-farm opportunities increased the returns to labour, and thus the opportunity cost of families keeping their children in school. Decentralizing fiscal reforms, on the other hand, shifted much of the responsibility for primary school funding to rural communities. This gave rise to differences in funding levels and possibly school quality. In poorer areas with weaker tax bases, high school fees reportedly discouraged enrollment.

Some observers suggest that these developments contributed to growing differences across communities and regions in average levels of educational attainment. Possibly counteracting these effects are the potential effects of increased household income and an increase in the returns to schooling on the demand for education. ${ }^{27}$

We cannot address these issues here, but are interested in the potential effect of differences in educational attainment on inequality. First, differences in schooling levels across villages can be an important source of inter-village differences in income, especially in an environment in which the returns to education are positive. There are also differences in educational attainment levels across families within villages. These differences can be a product of differences across age-sex cohorts in educational attainment and differences in the demographic composition of households, or can arise from differences within age-sex cohorts in schooling levels. The source of the inequality in educational attainment has potentially important implications for our interpretation of inequality in China and for policy.

${ }^{25}$ Schooling was severely disrupted during the famine between 1959 and 1961, and again in the mid-1960s, which explains some of the differences between later cohorts.

${ }^{26}$ See Kai-yuen Tsui (1997), Lavely, Xiao, Li, and Freedman (1990), and Emily Hannum (1998).

${ }^{27}$ As noted in our previous discussion, returns to education appear to have been zero, prior to the reforms. 
Using as our measure of household schooling the average number of years of completed schooling of all household members 16 years and older that are not currently enrolled, we carried out decomposition exercises analogous to those performed for income. We are interested in assessing the contribution of inter-village and inter-cohort differences to overall school inequality. Several findings emerge. Differences in average years of schooling across villages only explains about 10 percent of the differences in schooling levels across households in our sample. In other words, most of the differences are within villages, and either arise from differences across age cohorts or within age cohorts. An examination of our household data reveal that differences across age cohorts are very stark: average schooling increases from 1.8 years for individuals $61+$; to 5.1 for individuals $46-60 ; 6.2$ for age group 3145; 7.1 for 21-30,; and 7.6 years for the cohort aged 16-20. ${ }^{28}$ These differences are the source of another 25 percent of the variation in average household schooling. Together, these factors explain slightly more than a third of the variation in household schooling, leaving nearly two thirds unexplained by age-cohort or village.

Returning to the income inequality summaries, Table 9 shows the regression results, with a variety of control variables. In columns I and III, we show results from a "lean" specification with simple summaries of factor-inequality: the Gini for per capita land and the Gini for average household education inequality, as well as some simple market/institutional variables. The market variables are: 1) The estimated rate of return to schooling; 2) The distance to major markets (county seat); 3) The share of income from non-agricultural sources; 4) The share of the village labour force employed in TVE's; and 5) the fraction of output sold (as opposed to self-consumed). The village marketing variables (distance, employment in TVE's, and the share of crops sold to markets) are taken from a separate village questionnaire, while the remaining variables are estimated from the household survey. Very few coefficients in the lean specification are significant, though the sign patterns are in line with what we

\footnotetext{
28 These numbers probably slightly underestimate differences in schooling levels across cohorts because these calculations exclude village migrants who tended to be both younger and better educated.
} 
expect given a simple model linking income to factor endowments and prices. Income inequality is higher in those villages where a higher fraction of income is earned from non-agricultural activities; and lower the closer a village is to the county seat, the more commercialized is agriculture, and the higher the fraction of the labour force employed by TVE's. The coefficients in the consumption inequality equation are generally less significant than the income regressions.

The most interesting results appear when we add interactions between the human capital distribution and the "institutional" measures. One way to think of these variables is that they proxy various dimensions of market opportunities. It comes as no surprise that there are interactions between the distribution of human capital, and the degree of market opportunity (reflecting the level of economic development, or the extent of "transition"). Interpreting interaction effects can be tricky, so we discuss the coefficients in some detail. Consider first the distribution of education. To help with interpretation, note that inequality of education is negatively correlated with the average level of schooling; that is, in villages where average schooling levels are higher, the Gini of education is lower. The total effect of education on income inequality depends on all of the interaction effects.

We begin with the separate partial effects, which show where the inequality of schooling is more or less disequalizing. First, where land inequality is higher, the disequalizing effect of education is lower. This may be a product of the land allocation process, where higher land inequality results from land being allocated from the more educated households with better off-farm opportunities. Second, there is a strong positive interaction between the distribution and returns to schooling: where education is unequally distributed, and its return highest, inequality is also highest. This suggests that policies that reduce the returns to schooling, or decrease education inequality (increasing school attainment should do both) will reduce inequality. We return to this point shortly. Third, the institutional variables affect the impact of schooling on inequality. The further a village is from a county seat, the smaller is the disequalizing effect of human capital. In other words, the distribution of education matters less in more remote villages. A similar interpretation applies to the commercialization variable. Unequal educational outcomes adversely 
affect income inequality most when accompanied by commercial development. On the other hand, employment opportunities in TVE's reduce the adverse effect of education inequality, presumably by providing income opportunities for the less educated.

The institutional variables and their interactions with education can also be viewed on their own (as opposed to partial effects of education). The total institutional effects include the interaction terms, evaluated at some level of schooling inequality. For example, the median Gini of education inequality is 0.16 (it ranges from 0.08 to 0.28 , with most lying between 0.15 and 0.21 ). The total effect of an increase in the rate of return to schooling on the Gini of income inequality is $-2.486+(17.038 \times 0.16)=0.24$, so that an increase in the rate of return to schooling by 1 percentage point $(0.01)$ adds 0.0024 points to the Gini coefficient in a village with a median level of education inequality. ${ }^{29}$ We obtain several interesting and statistically significant results. First, inequality is higher the further away a village is from the county seat. Economic opportunity, as represented by distance to markets, has an equalizing effect on income. However, inequality of education erodes the positive effect of market integration, and inequality worsens when opportunities exist in villages with unequal distributions of schooling. Second, the more commercialized a village, the lower its Gini. Again, this indicator of market transition worsens inequality when combined with education inequality. Viewed differently, commercialization reinforces the positive effects of a more equal distribution of human capital. Finally, TVE employment worsens inequality if education inequality is zero, but it improves the income distribution for any Gini above 0.17 , which means any Gini above the median.

In summary, there are important interactions between human capital and market development in determining the level of inequality at the village level. Generally, commercialization and economic opportunity equalize incomes. However, the effects are less benign when accompanied by an unequal

\footnotetext{
${ }^{29}$ In fact, 0.01 is a small change in the rate of return to schooling given the variation in our sample. While the sampling variation is also large (see Table 5), we estimate village rates of return to education at an average of 0.07 for income, with a standard deviation of 0.08 (the $25-75$ percentile split is 0.03 and 0.10 ); and an average of 0.04 for expenditure, with a standard deviation of 0.04 (the $25-75$ percentile split is 0.02 to 0.07 ).
} 
distribution of education, whereby these opportunities will presumably be taken advantage of most by the more educated, at the expense of a higher income inequality.

\section{Conclusions}

Our empirical explorations yield a number of suggestive results linking economic transition to income inequality in China. Two important themes emerge. First, is the apparent role that "economic opportunity" plays in determining the relative position of winners and losers in transition. Second, is the

role that human capital plays in allowing households to access these opportunities. Inequality of economic development interacts with the unequal distribution of human capital, leading to more inequality within villages than differences of income across villages. One relatively pessimistic implication of our results is that rural inequality is likely to worsen before it improves. The distribution of human capital likely changes quite slowly, while market institutions and opportunities may change rapidly. Given the current distribution of education, many of these institutional developments will disproportionately benefit the higher educated. Compounding this, current patterns of capital accumulation suggest that the rich will be better positioned to increase their incomes, and thus their future wealth.

Of course, many questions remain unanswered, and our results provoke more questions than they answer. For example, we ignore the role of households as an economic institution. We also ignore cohort dimensions to inequality. For example, is education primarily unequally distributed among generations (cohorts), or is there considerable inequality of education within all age groups? The answers to these questions have important implications for the likely speed with which the education distribution, and thus the income distribution, will evolve. Nevertheless, our explorations suggest a number of important avenues for future empirical work, and highlight the importance of collecting new household survey data. 


\section{References}

An, Mark and Dennis Yang (1998): "Human Capital, Entrepreneurship, and Farm Household Earnings," mimeo, Duke University.

Benjamin, Dwayne and Loren Brandt (1997): "Land, Factor Markets, and Inequality in Rural China: Historical Evidence,” Explorations in Economic History, 34(4), October, pages 460-94.

Benjamin, Dwayne and Loren Brandt (1999): "Markets and Inequality in Rural China: Parallels with the Past,” American Economic Review, 89(2), May, pages 292-295.

Byrd, William and Alan Gelb (1990): "Township, Village and Private Enterprise in China's Economic Reform,” World Bank, Policy Research and External Affairs Working Papers Series, no. 406.

Cheng, Yuk-Shing (1996): “A Decomposition Analysis of Income Inequality of Chinese Rural Households," China Economic Review, 7(2), pp. 155-167.

Deaton, Angus (1997): The Analysis of Household Surveys, The World Bank, Washington D.C.

Deaton, Angus and Christina Paxson (1994): "Intertemporal Choice and Inequality," Journal of Political Economy,102(3), June, pages 437-67.

Glewwe, Paul and Margaret Grosh (1998): "The World Bank's Living Standards Measurement Study Household Surveys,” Journal of Economic Perspectives, 12(1), Winter, pp. 187-196.

Gregory, Robert and Xin Meng (1995): "Wage Determination and Occupational Attainment in the Rural Industrial Sector of China," Journal of Comparative Economics, 21, pages 353-374.

Guojia Jiwei Yanjiu Suo Ketizu (Chinese State Planning Commission, Economic Research Institution Research Group) (1995): "Woguo dongzhongxi san da diqu nongcun jingji fazhan chaju de fenxi,"(Analysis of Uneven Rural Economic Development of the Eastern, Central and Western Regions of China), Jingji Yanjiu Cankao (References on Economic Research),30, pp 2-42.

Hannum, Emily (1998): "Educational Inequality: Hidden Consequences of the Reform Era in Rural China," Ph.D. Dissertation, University of Michigan.

Hare, Denise (1994): "Rural Nonagricultural Activities and Their Impact on the Distribution of Income: Evidence from Farm Households in Southern China,” China Economic Review, 41, pp 59-82.

Ho, Samuel (1994): Rural China in Transition, New York: Oxford University Press.

Howes, Stephen and Athar Hussain (1994): "Regional Growth and Inequality in Rural China," mimeograph, London School of Economics.

Hussain, Athar, Peter Lanjouw, and Nicholas Stern (1994): "Income Inequalities in China: Evidence from Household Survey Data,” World Development, 22(12), pp. 1947-57.

Khan, Azizur and Carl Riskin (1998): "Income and Inequality in China: Composition, Distribution and Growth of Household Income, 1988 to 1995," China Quarterly, 154, pp. 221-251. 
Knight, John and Li Shi (1997): "Cumulative Causation and Inequality Among Villages in China," Oxford Development Studies, 25.2, pages. 149-172.

Knight, John and Lina Song (1993), "The Spatial Contribution to Income in Inequality in Rural China," Cambridge Journal of Economics, 17, pages 195-213.

Lardy, Nicholas (1994): China in the World Economy, Institute for International Economics: Washington, D.C.

Lavely, William, Zhenyu Xiao, Bohua Li, and Ronald Freedman (1990): “The Rise in Female Education in China: National and Regional Patterns," China Quarterly, 121, pp. 61-93.

Li Tianyou and Junsen Zhang (1998), "Returns to Education under Collective and Household Farming in China," Journal of Development Economics, 56 (2), pages 307-335.

Lin, Justin (1992): "Rural Reforms and Agricultural Growth in China, American Economic Review, 82.1, pages 34-51.

Ministry of Agriculture (1995): Zhongguo Nongye Fazhan Baogao '95 (China's Agricultural Development Report, 1995). Beijing: Zhongguo Nongye Chubanshe.

Morduch, Jonathan and Terry Sicular (1999): "Politics, Growth, and Inequality in Rural China: Does it Pay to Join the Party?," Mimeo, The University of Western Ontario.

Naughton, Barry (1996): Growing out of Plan, New York: Cambridge University Press.

Orazem, Peter and Milan Vodopivec (1995): "Winners and Losers in Transition: Returns to Education, Experience, and Gender in Slovenia,” World Bank Economic Review, 9(2), May, pages 201-230.

Park, Albert and Scott Rozelle (1998): "Reforming State-Market Relations in Rural China," mimeo, University of Michigan.

Psacharapoulos, George (1985): "Returns to Education: Further International Update and Implications," Journal of Human Resources, 20(4), December, pages 583-604.

Putterman, Louis (1993): Continuity and Change in China's Rural Development : Collective and Reform Eras in Perspective, New York: Oxford University Press.

Ravallion, Martin and Shaohua Chen (1996): "Data in Transition: Assessing Rural Living Standards in Southern China," China Economic Review; 7(1), Spring, pages 23-56.

Riskin, Carl (1994): “Chinese Rural Poverty: Marginalized or Dispersed?” American Economic Review, 84(2), May, pages 281-284.

Rosenzweig, Mark (1995): “Why Are There Returns to Schooling?” American Economic Review, 85(2), May, Pages 153-158.

Rozelle, Scott (1994), "Rural Industrialization and Increasing Inequality: Emerging Patterns in China's Reforming Economy," Journal of Comparative Economics, 19, pp. 362-391. 
Schultz, Theodore W. (1975): "The Ability to Deal with Disequilibria," Journal of Economic Literature, 13(3), September, pages 827-46.

Shorrocks, Anthony (1982): "Inequality Decomposition by Factor Components," Econometrica, 50(1), Jan. 1982, pages 193-211.

Shorrocks, Anthony (1983): “The Impact of Income Components on the Distribution of Family Incomes," Quarterly Journal of Economics, 98(2), May, pages 311-26.

Sicular, Terry (1995): "Redefining State, Plan, and Market: China's Reforms in Agricultural Commerce," China Quarterly, vol. 144, pages 1020-1046.

State Statistical Bureau: Zhongguo Tongji Nianjian, (Statistical Yearbook of China), Beijing, selected years.

Tsui, Kai-Yuen (1998): "Factor Decomposition of Chinese Rural Income Inequality: New Methodology, Empirical Findings, and Policy Implications,” Journal of Comparative Economics, 26, pages. 502- 528.

Tsui, Kai-Yuen (1997): "Economic Reform and Attainment in Basic Education in China,” China Quarterly, 149, pp. 104-12.

Tsui, Kai-Yuen (1991): “China's Regional Inequality, 1952-1985,” Journal of Comparative Economics, 15(1), March, pp. 1-21.

Turner, Matthew, Loren Brandt and Scott Rozelle (1999): "Property Rights Formation and the Organization of Exchange in Rural China", mimeo, University of Toronto.

Van Luong, Hy and Jonathan Unger (1998) "Wealth, Power, and Poverty in the Transition to Market Economies: The Process of Socio-Economic Differentiation in Rural China and Northern Vietnam," The China Journal, No. 40, July, pages 61-93.

Vermeer, E.B. (1982): “Income Differentials in Rural China,” China Quarterly, 111, pp. 1-33.

West, Lorraine and Yaohui Zhao, Editors (1999): The Flow of Rural Labor in China. Berkeley: University of California Press.

Yang, Dennis (1997), "Education and Off-farm Work," Economic Development and Cultural Change, 45, pp. 613-32.

Yang, Dennis (1999): “Urban-Biased Policies and Rising Income Inequality in China," American Economic Review, 89(2), pages 306-310.

Zhao Yaohui (1999): "Leaving the Countryside: Rural to Urban Migration Decisions in China," American Economic Review, 89(2), pages 281-286. 


\section{Figure 1: Spatial (RuRal) Inequality ACross Provinces of China GINI COEFFICIENT}

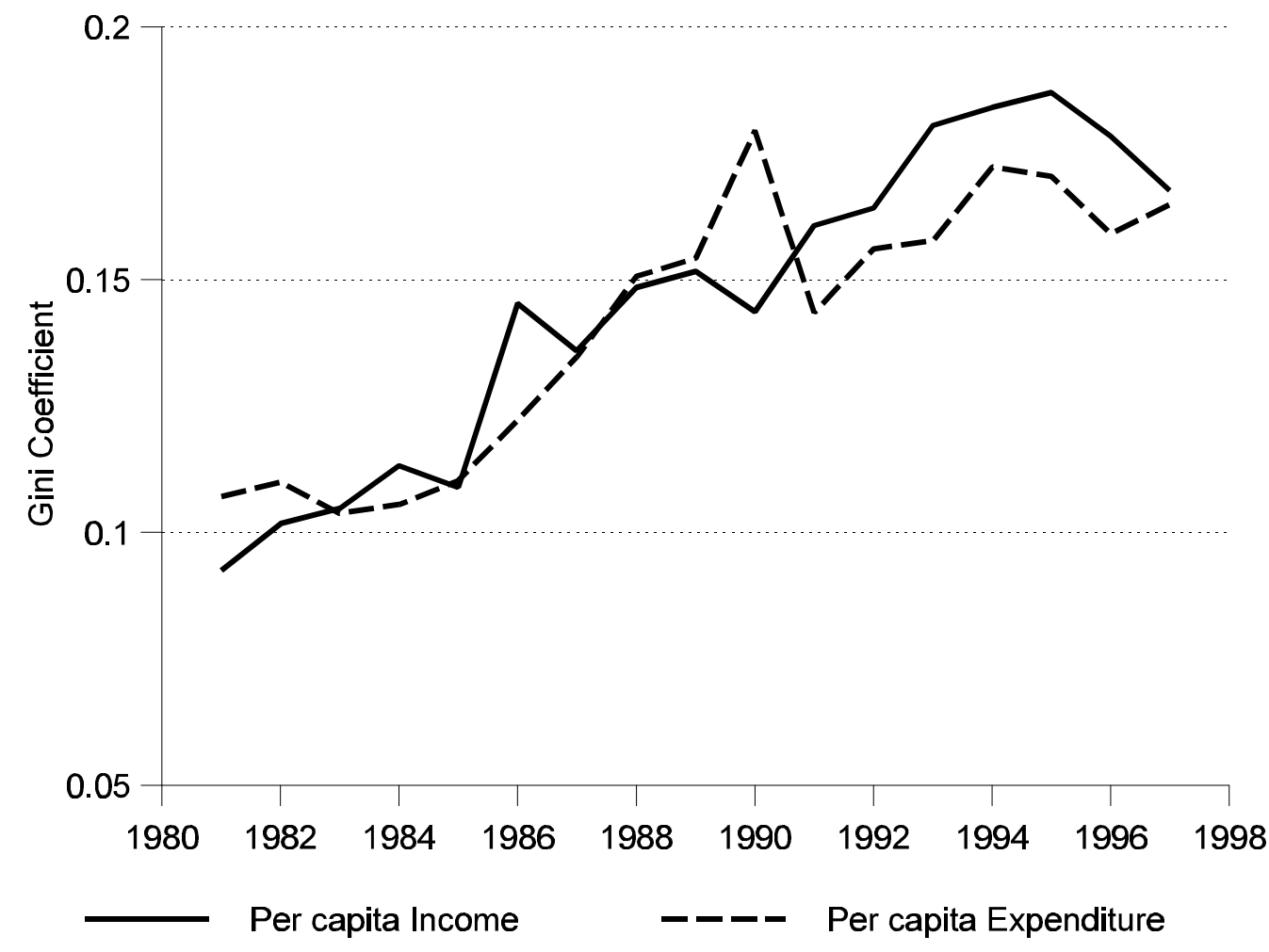

Notes: This figure shows the simulated level of inequality (Gini coefficient), assuming that everyone in a province has the same living standards (per capita income or consumption).

Source: Author's calculations based on rural household survey data of the State Statistical Bureau. Provincial means are reported on an annual basis in Zhongguo Tongji Nianjian (Statistical Yearbook of China), various years. 
Figure 2: SAMple Provinces and Rural Per Capita Income, 1994

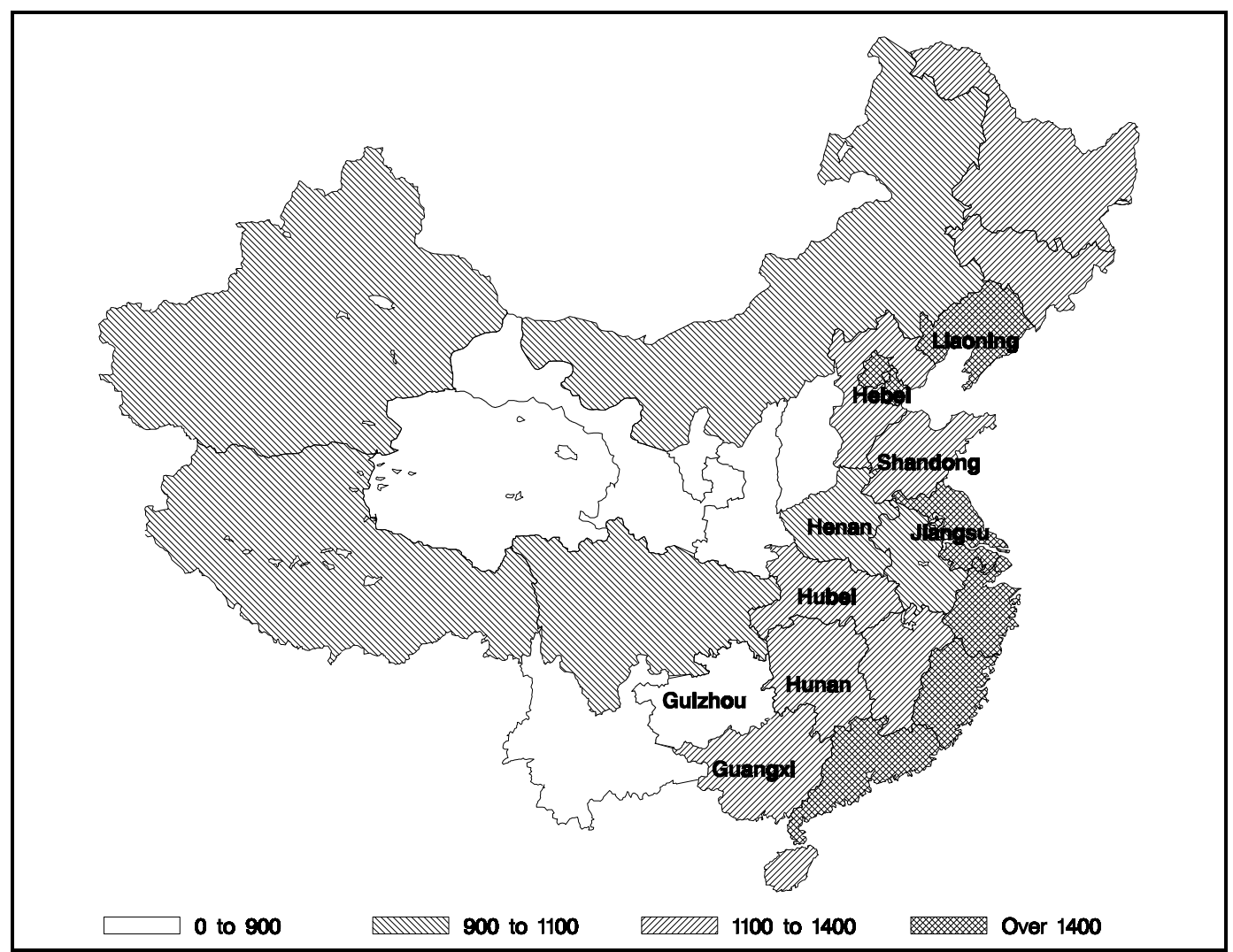

Notes: Map shows average provincial per capita income in 1994. Provinces sampled by CHNS and NCLSS are also labelled.

Source: Author's calculations based on rural household survey data of the State Statistical Bureau. Provincial means are reported on an annual basis in Zhongguo Tongji Nianjian (Statistical Yearbook of China), various years. 


\section{FigURE 3: KERNEL DENSITY ESTIMATES OF LOG PER CAPITA INCOME AND EXPENDITURE}

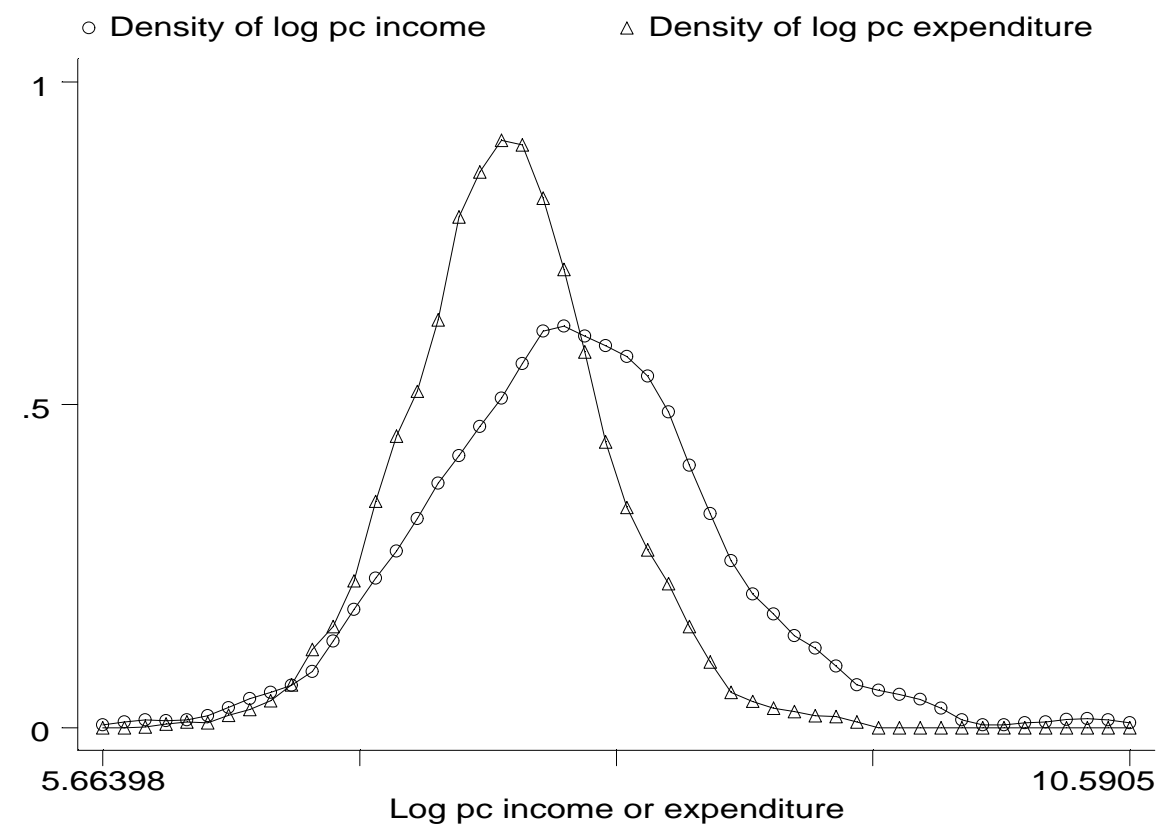


TABLE 1

SOURCES AND DISTRIBUTION OF HOUSEHOLD INCOME

\begin{tabular}{lccc}
\hline \hline Source of Income: & Mean & $\begin{array}{c}\text { Percentage } \\
\text { Not Zero }\end{array}$ & $\begin{array}{c}\text { Gini } \\
\text { Coefficient }\end{array}$ \\
\hline Men's Wages & 1578 & 41 & .41 \\
Women's Wages & 412 & 16 & .40 \\
Farm income & 5714 & 98 & .48 \\
Animal Husbandry & 1506 & 77 & .75 \\
Non-agricultural Family Enterprises & 1837 & 30 & .64 \\
Other income & 959 & 65 & .66 \\
Imputed Capital Services (House + durables) & 1065 & 100 & .39 \\
Total Income & 13071 & 100 & .40 \\
Total Expenditure & 8378 & 100 & .28 \\
Per Capita Income & 3510 & 100 & .39 \\
Per Capita Expenditure & 2250 & 100 & .26 \\
\hline
\end{tabular}

Notes: 1) Means are presented over the whole sample (778 households) in the first two columns. 2) The Gini Coefficient is calculated only over those households with positive income from that particular source. 3) Total Income is the sum of income from all sources including the imputed value of owner occupied housing and durables (Imputed Capital Services). Similarly, Total Expenditure includes the value of imputed capital services. 4) Farm Income includes crop income, plus income from agricultural sidelines (vegetables, fruit, wood, and greenhouses) and income from the sale of crop by-products. 5) Animal husbandry includes income from animal husbandry plus aqua-culture and agricultural businesses reported in the "family run business" section of the survey that are mostly poultry farms. 6) Non-agricultural Family enterprises are family run businesses that are not directly "agricultural." 7) Other income includes rental income, remittances, transfer income, and interest income. 
TABLE 2

Proportion OF INCOME VARIATION / INEQUALITY EXPLAINED BY LOCATION

\begin{tabular}{|c|c|c|c|c|}
\hline & TOTAL & Province & County & Village \\
\hline \multicolumn{5}{|c|}{ Per Capita Expenditure, 1995 Survey } \\
\hline Gini & .261 & & & \\
\hline Variance of $\log (\mathrm{pcx})$ & .219 & .090 & .167 & .249 \\
\hline Theil L & .101 & .097 & .169 & .304 \\
\hline Theil $\mathrm{T}$ & .128 & .077 & .130 & .248 \\
\hline \multicolumn{5}{|c|}{ Per Capita Income, 1995 Survey } \\
\hline Gini & .385 & & & \\
\hline Variance of $\log (\mathrm{pcy})$ & .464 & .057 & .117 & .245 \\
\hline Theil L & .238 & .098 & .167 & .329 \\
\hline Theil T & .291 & .080 & .134 & .305 \\
\hline \multicolumn{5}{|c|}{ Per Capita Income, CHNS 1993 Survey } \\
\hline Gini & .495 & & & \\
\hline Variance of $\log (\mathrm{pcy})$ & 1.175 & .036 & .151 & .267 \\
\hline Theil L & .496 & .073 & .166 & .290 \\
\hline Theil T & .469 & .076 & .173 & .303 \\
\hline
\end{tabular}

Notes: 1) Sample size for the 1995 data is 773 for income, and 778 for expenditure. 2) Sample size for the 1993 CHNS is 1653 (positive income observations). 3) TOTAL indicates the total sample inequality for each measure of inequality; 4) The remaining three columns show the proportion of each inequality index that is explained by differences in income across different geographic units (province, county, and village). 5) For the 1995 data, there are 5 villages in each of 6 counties (30 villages), split evenly between two provinces; 6) For the CHNS data, there are 3 villages in 4 counties in each of 8 provinces (for a total of 32 counties and 96 villages). 
TABLE 3

DECOMPOSITIONS OF INCOME INEQUALITY BY SOURCE OF INCOME

\begin{tabular}{|c|c|c|c|c|c|c|}
\hline & \multicolumn{3}{|c|}{ Full 1995 Sample } & \multicolumn{3}{|c|}{$\begin{array}{c}1995 \text { Sample } \\
\text { Excluding Highest Income }\end{array}$} \\
\hline & Share & OLS & 2SLS & Share & OLS & 2SLS \\
\hline \multicolumn{7}{|l|}{ Source: } \\
\hline Other Income & 0.073 & 0.061 & 0.090 & 0.072 & 0.047 & 0.080 \\
\hline Durables and Housing & 0.081 & 0.029 & 0.059 & 0.082 & 0.035 & 0.077 \\
\hline Men's Wages & 0.120 & 0.023 & 0.054 & 0.123 & 0.031 & 0.075 \\
\hline Women's wages & 0.031 & -0.001 & 0.015 & 0.032 & 0.000 & 0.020 \\
\hline Crop income & 0.435 & 0.236 & 0.178 & 0.444 & 0.302 & 0.247 \\
\hline Non-Ag Businesses & 0.141 & 0.433 & 0.478 & 0.125 & 0.312 & 0.333 \\
\hline Animal Husbandry & 0.119 & 0.219 & 0.125 & 0.122 & 0.273 & 0.168 \\
\hline \multicolumn{7}{|c|}{ CHNS 1993 Sample } \\
\hline & Mean & Share & OLS & & & \\
\hline Other Income (per capita) & 82 & 0.096 & 0.029 & & & \\
\hline Wage Income (per capita) & 206 & 0.240 & 0.147 & & & \\
\hline Crop Income (per capita) & 294 & 0.344 & 0.132 & & & \\
\hline Non-Ag Businesses (per capita) & 187 & 0.219 & 0.379 & & & \\
\hline Animal Husbandry (per capita) & 51 & 0.059 & 0.287 & & & \\
\hline Total Per Capita Income & 856 & & & & & \\
\hline
\end{tabular}

Notes: 1) The shares are the percentages of household income accounted for by each source of income. 2) OLS is the OLS estimate of the correlation between total per capita income and the per capita income of a given type. 3) 2SLS is the 2SLS estimate of this correlation, using total per capita expenditure (less capital services) as an instrument. This instrument is not available for the CHNS sample. 4) All means and correlations are reported weighted by the number of individuals in the household. 5) The income sources for the 1995 sample are described in Table 1. 6) For the CHNS, analogous income categories are created. Sample size in the CHNS is 1653 (the number of households with positive income). 
TABLE 4

DECOMPOSITIONS OF INCOME INEQUALITY BY SOURCE OF INCOME INTERACTIONS WITH SPATIAL INEQUALITY

\begin{tabular}{|c|c|c|c|c|c|}
\hline & \multicolumn{5}{|c|}{ Full 1995 Sample } \\
\hline & \multirow[b]{2}{*}{ Share } & \multicolumn{2}{|c|}{$\begin{array}{c}\text { Coefficients on PCY } \\
\text { With Village Fixed Effects }\end{array}$} & \multicolumn{2}{|c|}{$\begin{array}{l}\text { F-Tests for Different } \\
\text { Coefficients by Village }\end{array}$} \\
\hline & & OLS & 2SLS & OLS & 2SLS \\
\hline \multicolumn{6}{|l|}{ Source: } \\
\hline Other Income & 0.073 & 0.064 & .101 & $4.71(.000)$ & $1.22(.201)$ \\
\hline Durables and Housing & 0.081 & 0.024 & .059 & $3.51(.000)$ & $1.65(.018)$ \\
\hline Men's Wages & 0.120 & 0.029 & .070 & $6.20(.000)$ & $1.21(.204)$ \\
\hline Women's wages & 0.031 & -0.001 & .013 & $0.72(.862)$ & $1.02(.438)$ \\
\hline Crop income & 0.435 & 0.179 & .073 & $10.95(.000)$ & $1.81(.006)$ \\
\hline Non-Ag Businesses & 0.141 & 0.468 & .560 & $10.09(.000)$ & $1.28(.151)$ \\
\hline \multirow[t]{2}{*}{ Animal Husbandry } & 0.119 & 0.237 & .122 & $5.69(.000)$ & $0.38(.999)$ \\
\hline & \multicolumn{5}{|c|}{1995 Sample Excluding Highest Income } \\
\hline Other Income & 0.072 & .048 & .089 & $4.73(.000)$ & $1.04(.416)$ \\
\hline Durables and Housing & 0.082 & .029 & .080 & $2.75(.000)$ & $0.91(.601)$ \\
\hline Men's Wages & 0.123 & .038 & .099 & $5.49(.000)$ & $1.04(.416)$ \\
\hline Women's wages & 0.032 & -.001 & .018 & $0.72(.869)$ & $1.00(.470)$ \\
\hline Crop income & 0.444 & .249 & .149 & $7.93(.000)$ & $1.33(.119)$ \\
\hline Non-Ag Businesses & 0.125 & .333 & .376 & $12.97(.000)$ & $1.48(.051)$ \\
\hline Animal Husbandry & 0.122 & .304 & .189 & $14.13(.000)$ & $0.82(.074)$ \\
\hline
\end{tabular}

Notes: 1) All specifications are the same as in table 3, except village fixed effects have been added. 2) The F-tests (p-values in parentheses) are tests of the joint significance of the village $\times$ income interaction terms in a separate analysis of covariance specification. 3) The shares are the percentages of household income accounted for by each source of income. 4) OLS is the OLS estimate of the correlation between total per capita income and the per capita income of a given type (with village fixed effects). 5) 2SLS is the 2SLS estimate of this correlation, using total per capita expenditure (less capital services) and village interactions with this variable as instruments. 6) All means and correlations are reported weighted by the number of individuals in the household. 5) The income sources for the 1995 sample are described in Table 1. 
TABLE 5

Determinants of Household Per Capita Income ANd Consumption (standard errors in parentheses)

\begin{tabular}{|c|c|c|c|c|}
\hline & \multicolumn{2}{|c|}{$\ln \mathrm{PCY}$} & \multicolumn{2}{|c|}{$\ln \mathrm{PCX}$} \\
\hline & (I) & (II) & (III) & (IV) \\
\hline $\begin{array}{l}\text { Average Years of Schooling of Adults } \\
\text { in the Household }\end{array}$ & $\begin{array}{l}0.081 \\
(0.012)\end{array}$ & $\begin{array}{l}0.066 \\
(0.012)\end{array}$ & $\begin{array}{l}0.052 \\
(0.008)\end{array}$ & $\begin{array}{l}0.038 \\
(0.008)\end{array}$ \\
\hline $\begin{array}{l}\text { Number of members with Technical } \\
\text { Training }\end{array}$ & $\begin{array}{l}0.171 \\
(0.043)\end{array}$ & $\begin{array}{l}0.109 \\
(0.042)\end{array}$ & $\begin{array}{l}0.135 \\
(0.030)\end{array}$ & $\begin{array}{l}0.103 \\
(0.028)\end{array}$ \\
\hline $\begin{array}{l}\text { Number of members with apprentice } \\
\text { training }\end{array}$ & $\begin{array}{l}0.006 \\
(0.045)\end{array}$ & $\begin{array}{l}-0.016 \\
(0.043)\end{array}$ & $\begin{array}{l}0.040 \\
(0.031)\end{array}$ & $\begin{array}{l}0.016 \\
(0.028)\end{array}$ \\
\hline Indicator for having allocated land & $\begin{array}{l}-1.389 \\
(0.199)\end{array}$ & $\begin{array}{l}-1.093 \\
(0.218)\end{array}$ & $\begin{array}{l}-0.547 \\
(0.136)\end{array}$ & $\begin{array}{l}-0.441 \\
(0.145)\end{array}$ \\
\hline Log of allocated land & $\begin{array}{l}0.307 \\
(0.032)\end{array}$ & $\begin{array}{l}0.309 \\
(0.036)\end{array}$ & $\begin{array}{l}0.077 \\
(0.022)\end{array}$ & $\begin{array}{l}0.097 \\
(0.024)\end{array}$ \\
\hline Share of land suffering adverse shock & $\begin{array}{l}-0.558 \\
(0.143)\end{array}$ & $\begin{array}{l}-0.613 \\
(0.167)\end{array}$ & $\begin{array}{l}-0.073 \\
(0.098)\end{array}$ & $\begin{array}{l}-0.208 \\
(0.111)\end{array}$ \\
\hline Log Household Size & $\begin{array}{l}-0.510 \\
(0.086)\end{array}$ & $\begin{array}{l}-0.487 \\
(0.085)\end{array}$ & $\begin{array}{l}-0.370 \\
(0.059)\end{array}$ & $\begin{array}{l}-0.399 \\
(0.057)\end{array}$ \\
\hline F-Test for Village Fixed Effects & NA & $5.53(0.000)$ & NA & $7.23(0.000)$ \\
\hline F-Test for Village $\times$ Education & NA & $1.51(0.04)$ & NA & $1.22(0.20)$ \\
\hline$\underline{\text { R-Squared }}$ & 0.24 & .381 & .26 & .43 \\
\hline \multicolumn{5}{|c|}{$\begin{array}{l}\text { Notes: 1) The coefficients are from an OLS regression of ln PCY (per capita income) or ln PCX (per capita } \\
\text { expenditure) on the variables shown in the table, PLUS controls for land quality and household age-sex structure (the } \\
\text { coefficients of which are not shown). 2) In columns II and IV, village fixed effects are added, with the f-test and p- } \\
\text { value of the joint significance of the village fixed effects also reported. 3) In a separate specification, interaction effects } \\
\text { between village and education (years of schooling) are added to the same based village-fixed effects specification. The } \\
\text { F-tests for these interaction terms are reported in columns II and IV. 4) The sample sizes are } 773 \text { for income, and } 778 \\
\text { for expenditures. }\end{array}$} \\
\hline
\end{tabular}


TABLE 6

Probits for Household Engagement in VARIOUS ACTIVITIES (standard errors in parentheses)

\begin{tabular}{lcccc}
\hline \hline & Animal Husbandry & Male Wage Labour & $\begin{array}{c}\text { Female Wage } \\
\text { Labour }\end{array}$ & $\begin{array}{c}\text { Non-Ag } \\
\text { Business }\end{array}$ \\
\hline Mean Probability: & 0.78 & 0.43 & 0.19 & 0.33 \\
$\begin{array}{l}\text { Average Years of Schooling of Adults } \\
\text { in the Household }\end{array}$ & -0.072 & 0.076 & 0.151 & -0.006 \\
Number of members with Technical & $(0.038)$ & $(0.030)$ & $(0.042)$ & $(0.031)$ \\
Training & 0.150 & 0.241 & -0.092 & 0.183 \\
Number of members with apprentice & 0.032 & $(0.107)$ & $(0.121)$ & $(0.106)$ \\
training & $(0.127)$ & 0.182 & 0.017 & 0.299 \\
Indicator for having allocated land & -0.348 & $(0.108)$ & $(0.123)$ & $(0.106)$ \\
& $(0.582)$ & 0.838 & 1.760 & 0.17 \\
Log of allocated land & 0.129 & $(0.560)$ & -0.174 & $(0.573)$ \\
Share of land suffering adverse shock & $(0.102)$ & $(0.094)$ & -0.104 & -0.198 \\
& 0.043 & 0.059 & $(0.123)$ & $(0.099)$ \\
Log Household Size & $(0.492)$ & $(0.428)$ & 0.063 & -0.818 \\
& 0.312 & 0.564 & $(0.546)$ & $(0.461)$ \\
\hline
\end{tabular}

Notes: 1) The coefficients are the estimated coefficients from Probit estimation of whether a household has income from a particular source. 2) The fraction of households engaged in each activity is in the Mean Probability Row. 3) All equations include the same regressors as reported in table 5, including village fixed effects. Some of the village effects predict an activity perfectly. 4) All estimation is conducted with sample weights equal to household size. 
TABLE 7

Determinants of LeVels of Household Per Capita Income in VARious ACTIVITIES (standard errors in parentheses)

\begin{tabular}{|c|c|c|c|c|c|c|}
\hline & Crop Income & $\begin{array}{c}\text { Animal } \\
\text { Husbandry }\end{array}$ & $\begin{array}{l}\text { Male Wage } \\
\text { Labour }\end{array}$ & $\begin{array}{c}\text { Female Wage } \\
\text { Labour }\end{array}$ & $\begin{array}{l}\text { Non-Ag } \\
\text { Business }\end{array}$ & All Non-Crop \\
\hline $\begin{array}{l}\text { Average Years of Schooling of Adults in } \\
\text { the Household }\end{array}$ & $\begin{array}{c}0.020 \\
(0.013)\end{array}$ & $\begin{array}{c}0.021 \\
(0.045)\end{array}$ & $\begin{array}{l}0.088 \\
(0.026)\end{array}$ & $\begin{array}{l}0.177 \\
(0.062)\end{array}$ & $\begin{array}{l}0.084 \\
(0.061)\end{array}$ & $\begin{array}{l}0.098 \\
(0.026)\end{array}$ \\
\hline $\begin{array}{l}\text { Number of members with Technical } \\
\text { Training }\end{array}$ & $\begin{array}{l}-0.030 \\
(0.046)\end{array}$ & $\begin{array}{l}-0.080 \\
(0.146)\end{array}$ & $\begin{array}{l}0.178 \\
(0.084)\end{array}$ & $\begin{array}{l}0.204 \\
(0.139)\end{array}$ & $\begin{array}{l}0.133 \\
(0.193)\end{array}$ & $\begin{array}{l}0.237 \\
(0.088)\end{array}$ \\
\hline $\begin{array}{l}\text { Number of members with apprentice } \\
\text { training }\end{array}$ & $\begin{array}{l}-0.055 \\
(0.046)\end{array}$ & $\begin{array}{l}-0.244 \\
(0.163)\end{array}$ & $\begin{array}{l}0.050 \\
(0.086)\end{array}$ & $\begin{array}{l}-0.032 \\
(0.167)\end{array}$ & $\begin{array}{l}-0.050 \\
(0.179)\end{array}$ & $\begin{array}{l}0.101 \\
(0.091)\end{array}$ \\
\hline Indicator for having allocated land & $\begin{array}{l}-1.774 \\
(0.257)\end{array}$ & $\begin{array}{l}-1.952 \\
(0.981)\end{array}$ & $\begin{array}{l}0.794 \\
(0.528)\end{array}$ & $\begin{array}{l}2.660 \\
(1.347)\end{array}$ & $\begin{array}{l}-0.233 \\
(1.071)\end{array}$ & $\begin{array}{l}0.810 \\
(0.489)\end{array}$ \\
\hline Log of allocated land & $\begin{array}{l}0.775 \\
(0.039)\end{array}$ & $\begin{array}{c}0.181 \\
(0.145)\end{array}$ & $\begin{array}{l}-0.211 \\
(0.090)\end{array}$ & $\begin{array}{l}-0.176 \\
(0.187)\end{array}$ & $\begin{array}{l}0.123 \\
(0.202)\end{array}$ & $\begin{array}{l}-0.208 \\
(0.083)\end{array}$ \\
\hline Share of land suffering adverse shock & $\begin{array}{l}-0.942 \\
(0.180)\end{array}$ & $\begin{array}{l}-0.321 \\
(0.651)\end{array}$ & $\begin{array}{l}-0.168 \\
(0.394)\end{array}$ & $\begin{array}{l}-0.050 \\
(0.771)\end{array}$ & $\begin{array}{l}0.539 \\
(0.926)\end{array}$ & $\begin{array}{l}-0.073 \\
(0.369)\end{array}$ \\
\hline Log Household Size & $\begin{array}{l}-0.903 \\
(0.092)\end{array}$ & $\begin{array}{l}-0.239 \\
(0.329)\end{array}$ & $\begin{array}{l}-0.489 \\
(0.202)\end{array}$ & $\begin{array}{l}-0.948 \\
(0.424)\end{array}$ & $\begin{array}{l}-0.746 \\
(0.464)\end{array}$ & $\begin{array}{l}0.155 \\
(0.189)\end{array}$ \\
\hline Sample Size & 741 & 446 & 320 & 125 & 213 & 659 \\
\hline R-Squared & 0.62 & 0.233 & 0.42 & 0.63 & 0.28 & 0.23 \\
\hline
\end{tabular}

Notes: 1) The coefficients are estimated from regressions of log per capita income of each type on the same set of explanatory variables as described in table 5 (including village fixed effects). 2) Regressions are weighted by household size. 3) "All NonCrop" is income from all income categories except crops and "non-labor" income, i.e., the sum of animal husbandry, wage labour, and non-agricultural businesses. 
TABLE 8

SAVINGS AND ASSET ACCUMUlation

(standard errors in parentheses)

\begin{tabular}{|c|c|c|c|c|c|c|}
\hline & I & II & III & IV & $\mathbf{V}$ & VI \\
\hline Dependent Variable: & $\begin{array}{l}\text { Savings } \\
\text { "Rate" }\end{array}$ & $\begin{array}{c}\text { In per capita } \\
\text { Assets }\end{array}$ & $\begin{array}{c}\text { In per capita } \\
\text { Assets }\end{array}$ & $\begin{array}{c}\text { In per capita } \\
\text { Assets }\end{array}$ & $\begin{array}{c}\text { In per capita } \\
\text { Assets }\end{array}$ & $\begin{array}{c}\text { In per capita } \\
\text { Assets }\end{array}$ \\
\hline Explanatory Variable: & OLS & OLS & 2SLS & OLS & OLS & 2SLS \\
\hline Savings "Rate" & & & & & $\begin{array}{c}0.113 \\
(0.058)\end{array}$ & $\begin{array}{c}0.821 \\
(0.256)\end{array}$ \\
\hline Ln Per Capita Income & & $\begin{array}{c}0.602 \\
(0.049)\end{array}$ & $\begin{array}{c}1.493 \\
(0.118)\end{array}$ & & & \\
\hline $\begin{array}{l}\text { Average Years of Schooling of the } \\
\text { adults in the household }\end{array}$ & $\begin{array}{c}0.028 \\
(0.011)\end{array}$ & & & $\begin{array}{c}0.081 \\
(0.018)\end{array}$ & $\begin{array}{c}0.101 \\
(0.015)\end{array}$ & $\begin{array}{c}0.091 \\
(0.017)\end{array}$ \\
\hline $\begin{array}{l}\text { Number of members with Technical } \\
\text { Training }\end{array}$ & $\begin{array}{c}0.006 \\
(0.039)\end{array}$ & & & $\begin{array}{c}0.246 \\
(0.063)\end{array}$ & $\begin{array}{c}0.221 \\
(0.062)\end{array}$ & $\begin{array}{c}0.237 \\
(0.068)\end{array}$ \\
\hline $\begin{array}{l}\text { Number of members with apprentice } \\
\text { training }\end{array}$ & $\begin{array}{l}-0.032 \\
(0.040)\end{array}$ & & & $\begin{array}{c}0.117 \\
(0.064)\end{array}$ & $\begin{array}{c}0.100 \\
(0.063)\end{array}$ & $\begin{array}{c}0.120 \\
(0.069)\end{array}$ \\
\hline $\begin{array}{l}\text { Fraction of Land suffering adverse } \\
\text { shock }\end{array}$ & $\begin{array}{l}-0.408 \\
(0.158)\end{array}$ & & & $\begin{array}{l}-0.563 \\
(0.252)\end{array}$ & & \\
\hline R-Squared & 0.17 & 0.28 & - & 0.27 & 0.23 & 0.07 \\
\hline
\end{tabular}

Notes: 1) Savings is measured as $\ln ($ income) - $\ln$ (expenditure); 2) Assets are measured as $\ln$ (per capita assets); 3) All

specifications include village fixed effects. 4) For specification I and IV, additional controls are the same as in Tables 5-7. 5) For specification II, only the village fixed effects are included, as well as lnpcy; 6) For specification III, lnpcy is instrumented with lnpcx, as in Table 3. 7) For specification V, only the education, log household size, and land indicators, as well as the village fixed effects are included as controls. 8) In specification VI, the savings rate is instrumented by the shock variable, farm size, and the ratio of kids and teens. The overidentification test is 1.96 (distributed P2(5) under the null hypothesis of no correlation between identifying instruments and error term) which is insignificant at conventional levels. 
TABLE 9

Summarizing Patterns of Village Inequality

(Standard errors in parentheses)

\begin{tabular}{|c|c|c|c|c|}
\hline & \multicolumn{2}{|c|}{ Gini Per Capita Income } & \multicolumn{2}{|c|}{ Gini of Per Capita Expenditure } \\
\hline & OLS & OLS & OLS & OLS \\
\hline & (I) & (II) & (III) & (IV) \\
\hline Gini of Education & $\begin{array}{c}0.105 \\
(0.260)\end{array}$ & $\begin{array}{l}-1.667 \\
(0.733)\end{array}$ & $\begin{array}{c}0.251 \\
(0.220)\end{array}$ & $\begin{array}{c}0.200 \\
(0.882)\end{array}$ \\
\hline Gini of Per Capita land & $\begin{array}{c}0.162 \\
(0.101)\end{array}$ & $\begin{array}{c}0.871 \\
(0.325)\end{array}$ & $\begin{array}{l}0.061 \\
(0.071)\end{array}$ & $\begin{array}{c}0.748 \\
(0.337)\end{array}$ \\
\hline Gini of Land $\times$ Gini of Education & & $\begin{array}{l}-5.885 \\
(1.933)\end{array}$ & & $\begin{array}{l}-4.819 \\
(1.983)\end{array}$ \\
\hline Rate of Return to Schooling (income) & $\begin{array}{c}0.301 \\
(0.161)\end{array}$ & $\begin{array}{l}-2.486 \\
(0.607)\end{array}$ & & \\
\hline Rate of Return to Schooling (expend) & & & $\begin{array}{l}0.006 \\
(0.197)\end{array}$ & $\begin{array}{c}1.430 \\
(0.998)\end{array}$ \\
\hline Gini of Ed $\times$ Rate of Return & & $\begin{array}{l}17.038 \\
(3.565)\end{array}$ & & $\begin{array}{l}-8.983 \\
(6.031)\end{array}$ \\
\hline Share of income from Non-ag business & $\begin{array}{c}0.167 \\
(0.082)\end{array}$ & $\begin{array}{l}-0.140 \\
(0.090)\end{array}$ & $\begin{array}{l}-0.065 \\
(0.065)\end{array}$ & $\begin{array}{l}-0.147 \\
(0.118)\end{array}$ \\
\hline Share of non-ag $\times$ Gini of Education & & $\begin{array}{c}0.000 \\
(0.000)\end{array}$ & & $\begin{array}{c}0.000 \\
(0.000)\end{array}$ \\
\hline Distance from County Seat & $\begin{array}{c}0.000 \\
(0.000)\end{array}$ & $\begin{array}{c}0.004 \\
(0.001)\end{array}$ & $\begin{array}{l}0.000 \\
(0.000)\end{array}$ & $\begin{array}{c}0.001 \\
(0.001)\end{array}$ \\
\hline Distance $\times$ Gini of Education & & $\begin{array}{l}-0.015 \\
(0.004)\end{array}$ & & $\begin{array}{l}-0.008 \\
(0.005)\end{array}$ \\
\hline Fraction of Ag output sold & $\begin{array}{l}-0.001 \\
(0.000)\end{array}$ & $\begin{array}{l}-0.008 \\
(0.002)\end{array}$ & $\begin{array}{l}-0.001 \\
(0.000)\end{array}$ & $\begin{array}{l}-0.007 \\
(0.002)\end{array}$ \\
\hline Fraction Sold $\times$ Gini of Education & & $\begin{array}{c}0.039 \\
(0.009)\end{array}$ & & $\begin{array}{c}0.034 \\
(0.011)\end{array}$ \\
\hline Fraction Employed in Rural Enterprises & $\begin{array}{l}-0.060 \\
(0.083)\end{array}$ & $\begin{array}{c}0.603 \\
(0.230)\end{array}$ & $\begin{array}{l}-0.012 \\
(0.070)\end{array}$ & $\begin{array}{c}1.110 \\
(0.342)\end{array}$ \\
\hline TVE $\times$ Gini of Education & & $\begin{array}{l}-3.673 \\
(1.327)\end{array}$ & & $\begin{array}{l}-6.628 \\
(1.968)\end{array}$ \\
\hline$\underline{\mathrm{R} \text {-squared }}$ & 0.610 & 0.920 & 0.340 & 0.700 \\
\hline
\end{tabular}

Notes: 1) The coefficients are estimated from a regression of the village-level Gini-coefficient for per capita income and expenditure on the variables listed above. 2) All regressions are weighted by village population. 3) The rate of return to schooling at the village level is estimated from the interaction effects in the income and expenditure regressions reported in Table 5. 


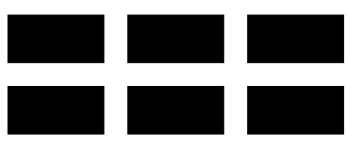

THE WILLIAM DAVIDSON INSTITUTE

AT THE UNIVERSITY OF MICHIGAN BUSINESSSCHOOL

\section{DAVIDSON INSTITUTE WORKING PAPER SERIES}

CURRENT AS OF 4/27/00

\begin{tabular}{|c|c|c|}
\hline Publication & Authors & Date of Paper \\
\hline $\begin{array}{l}\text { No. } 320 \text { Rethinking Marketing Programs for } \\
\text { Emerging Markets }\end{array}$ & Niraj Dawar and Amitava Chattopadhyay & June 2000 \\
\hline $\begin{array}{l}\text { No. } 319 \text { Public Finance and Low Equilibria in } \\
\text { Transition Economies; the Role of Institutions }\end{array}$ & Daniel Daianu and Radu Vranceanu & June 2000 \\
\hline $\begin{array}{l}\text { No. } 318 \text { Some Econometric Evidence on the } \\
\text { Effectiveness of Active Labour Market } \\
\text { Programmes in East Germany }\end{array}$ & Martin Eichler and Michael Lechner & June 2000 \\
\hline $\begin{array}{l}\text { No. } 317 \text { A Model of Russia's "Virtual } \\
\text { Economy” }\end{array}$ & R.E Ericson and B.W Ickes & May 2000 \\
\hline $\begin{array}{l}\text { No. } 316 \text { Financial Institutions, Financial } \\
\text { Contagion, and Financial Crises }\end{array}$ & Haizhou Huang and Chenggang Xu & March 2000 \\
\hline $\begin{array}{l}\text { No. } 315 \text { Privatization versus Regulation in } \\
\text { Developing Economies: The Case of West } \\
\text { African Banks }\end{array}$ & $\begin{array}{l}\text { Jean Paul Azam, Bruno Biais, and } \\
\text { Magueye Dia }\end{array}$ & February 2000 \\
\hline $\begin{array}{l}\text { No. } 314 \text { Is Life More Risky in the Open? } \\
\text { Household Risk-Coping and the Opening of } \\
\text { China's Labor Markets }\end{array}$ & John Giles & April 2000 \\
\hline $\begin{array}{l}\text { No. } 313 \text { Networks, Migration and Investment: } \\
\text { Insiders and Outsiders in Tirupur's } \\
\text { Production Cluster }\end{array}$ & Abhijit Banerjee and Kaivan Munshi & March 2000 \\
\hline $\begin{array}{l}\text { No. } 312 \text { Computational Analysis of the Impact } \\
\text { on India of the Uruguay Round and the } \\
\text { Forthcoming WTO Trade Negotiations }\end{array}$ & $\begin{array}{l}\text { Rajesh Chadha, Drusilla K. Brown, Alan } \\
\text { V. Deardorff and Robert M. Stern }\end{array}$ & March 2000 \\
\hline $\begin{array}{l}\text { No. } 311 \text { Subsidized Jobs for Unemployed } \\
\text { Workers in Slovakia }\end{array}$ & Jan. C. van Ours & May 2000 \\
\hline $\begin{array}{l}\text { No. } 310 \text { Determinants of Managerial Pay in } \\
\text { the Czech Republic }\end{array}$ & $\begin{array}{l}\text { Tor Eriksson, Jaromir Gottvald and Pavel } \\
\text { Mrazek }\end{array}$ & May 2000 \\
\hline $\begin{array}{l}\text { No. } 309 \text { The Great Human Capital } \\
\text { Reallocation: An Empirical Analysis of } \\
\text { Occupational Mobility in Transitional Russia }\end{array}$ & Klara Z. Sabirianova & May 2000 \\
\hline $\begin{array}{l}\text { No. } 308 \text { Economic Development, Legality, and } \\
\text { the Transplant Effect }\end{array}$ & $\begin{array}{l}\text { Daniel Berkowitz, Katharina Pistor, and } \\
\text { Jean-Francois Richard }\end{array}$ & February 2000 \\
\hline $\begin{array}{l}\text { No. } 307 \text { Community Participation, Teacher } \\
\text { Effort, and Educational Outcome: The Case of } \\
\text { El Salvador's EDUCO Program }\end{array}$ & Yasuyuki Sawada & November 1999 \\
\hline $\begin{array}{l}\text { No. } 306 \text { Gender Wage Gap and Segregation in } \\
\text { Late Transition }\end{array}$ & Stepan Jurajda & May 2000 \\
\hline $\begin{array}{l}\text { No. } 305 \text { The Gender Pay Gap in the } \\
\text { Transition from Communism: Some Empirical } \\
\text { Evidence }\end{array}$ & Andrew Newell and Barry Reilly & May 2000 \\
\hline $\begin{array}{l}\text { No. } 304 \text { Post-Unification Wage Growth in } \\
\text { East Germany }\end{array}$ & Jennifer Hunt & November 1998 \\
\hline $\begin{array}{l}\text { No. } 303 \text { How Does Privatization Affect } \\
\text { Workers? The Case of the Russian Mass } \\
\text { Privatization Program }\end{array}$ & Elizabeth Brainerd & May 2000 \\
\hline No. 302 Liability for Past Environmental & Dietrich Earnhart & March 2000 \\
\hline
\end{tabular}

Publications denoted by an asterisk are not available on the Kresge Library webpage (http://www.wdi.bus.umich.edu) 


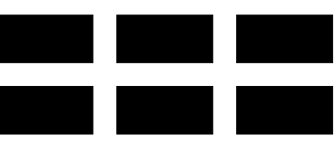

THE WILLIAM DAVIDSON INSTITUTE AT THE UNIVERSITY OF MICHIGAN BUSINESSSCHOOL

\begin{tabular}{|c|c|c|}
\hline Contamination and Privatization & & \\
\hline No. 301 Varieties, Jobs and EU Enlargement & Tito Boeri and Joaquim Oliveira Martins & May 2000 \\
\hline No. 300 Employer Size Effects in Russia & Todd Idson & April 2000 \\
\hline $\begin{array}{l}\text { No. } 299 \text { Information Complements, } \\
\text { Substitutes, and Strategic Product Design }\end{array}$ & $\begin{array}{l}\text { Geoffrey G. Parker and Marshall W. Van } \\
\text { Alstyne }\end{array}$ & March 2000 \\
\hline $\begin{array}{l}\text { No. } 298 \text { Markets, Human Capital, and } \\
\text { Inequality: Evidence from Rural China }\end{array}$ & $\begin{array}{l}\text { Dwayne Benjamin, Loren Brandt, Paul } \\
\text { Glewwe, and Li Guo }\end{array}$ & May 2000 \\
\hline $\begin{array}{l}\text { No. } 297 \text { Corporate Governance in the Asian } \\
\text { Financial Crisis }\end{array}$ & $\begin{array}{l}\text { Simon Johnson, Peter Boone, Alasdair } \\
\text { Breach, and Eric Friedman }\end{array}$ & November 1999 \\
\hline $\begin{array}{l}\text { No. } 296 \text { Competition and Firm Performance: } \\
\text { Lessons from Russia }\end{array}$ & J. David Brown and John S. Earle & March 2000 \\
\hline $\begin{array}{l}\text { No. } 295 \text { Wage Determination in Russia: An } \\
\text { Econometric Investigation }\end{array}$ & Peter J. Luke and Mark E. Schaffer & March 2000 \\
\hline $\begin{array}{l}\text { No. 294: Can Banks Promote Enterprise } \\
\text { Restructuring?: Evidence From a Polish } \\
\text { Bank's Experience }\end{array}$ & John P. Bonin and Bozena Leven & March 2000 \\
\hline $\begin{array}{l}\text { No. 293: Why do Governments Sell Privatised } \\
\text { Companies Abroad? }\end{array}$ & $\begin{array}{l}\text { Bernardo Bortolotti, Marcella Fantini and } \\
\text { Carlo Scarpa }\end{array}$ & March 2000 \\
\hline $\begin{array}{l}\text { No. 292: Going Public in Poland: Case-by- } \\
\text { Case Privatizations, Mass Privatization and } \\
\text { Private Sector Initial Public Offerings }\end{array}$ & Wolfgang Aussenegg & December 1999 \\
\hline $\begin{array}{l}\text { No. 291: Institutional Technology and the } \\
\text { Chains of Trust: Capital Markets and } \\
\text { Privatization in Russia and the Czech } \\
\text { Republic }\end{array}$ & Bruce Kogut and Andrew Spicer & March 1999 \\
\hline $\begin{array}{l}\text { No. 290: Banking Crises and Bank Rescues: } \\
\text { The Effect of Reputation }\end{array}$ & Jenny Corbett and Janet Mitchell & January 2000 \\
\hline $\begin{array}{l}\text { No. 289: Do Active Labor Market Policies } \\
\text { Help Unemployed Workers to Find and Keep } \\
\text { Regular Jobs? }\end{array}$ & Jan C. van Ours & February 2000 \\
\hline $\begin{array}{l}\text { No. 288: Consumption Patterns of the New } \\
\text { Elite in Zimbabwe }\end{array}$ & Russell Belk & February 2000 \\
\hline $\begin{array}{l}\text { No. 287: Barter in Transition Economies: } \\
\text { Competing Explanations Confront Ukranian } \\
\text { Data }\end{array}$ & $\begin{array}{l}\text { Dalia Marin, Daniel Kaufmann and } \\
\text { Bogdan Gorochowskij }\end{array}$ & January 2000 \\
\hline $\begin{array}{l}\text { No. 286: The Quest for Pension Reform: } \\
\text { Poland's Security through Diversity }\end{array}$ & Marek Góra and Michael Rutkowski & January 2000 \\
\hline $\begin{array}{l}\text { No. 285: Disorganization and Financial } \\
\text { Collapse }\end{array}$ & Dalia Marin and Monika Schnitzer & October 1999 \\
\hline $\begin{array}{l}\text { No. 284: Coordinating Changes in M-form } \\
\text { and U-form Organizations }\end{array}$ & $\begin{array}{l}\text { Yingyi Qian, Gérard Roland and } \\
\text { Chenggang } \mathrm{Xu}\end{array}$ & May 1999 \\
\hline $\begin{array}{l}\text { No. 283: Why Russian Workers Do Not Move: } \\
\text { Attachment of Workers Through In-Kind } \\
\text { Payments }\end{array}$ & Guido Friebel and Sergei Guriev & October 1999 \\
\hline $\begin{array}{l}\text { No. 282: Lessons From Fiascos in Russian } \\
\text { Corporate Governance }\end{array}$ & Merritt B. Fox and Michael A. Heller & October 1999 \\
\hline $\begin{array}{l}\text { No. 281: Income Distribution and Price } \\
\text { Controls: Targeting a Social Safety Net } \\
\text { During Economic Transition }\end{array}$ & Michael Alexeev and James Leitzel & March 1999 \\
\hline $\begin{array}{l}\text { No. 280: Starting Positions, Reform Speed, } \\
\text { and Economic Outcomes in Transitioning }\end{array}$ & William Hallagan and Zhang Jun & January 2000 \\
\hline
\end{tabular}

Publications denoted by an asterisk are not available on the Kresge Library webpage (http://www.wdi.bus.umich.edu) 


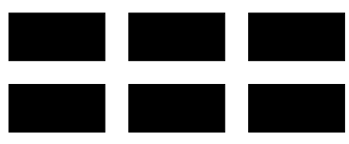

THE WILLIAM DAVIDSON INSTITUTE AT THE UNIVERSITY OF MICHIGAN BUSINESSSCHOOL

\begin{tabular}{|c|c|c|}
\hline Economies & & \\
\hline No. 279: The Value of Prominent Directors & Yoshiro Miwa \& J. Mark Ramseyer & October 1999 \\
\hline No. 278: The System Paradigm & János Kornai & April 1998 \\
\hline $\begin{array}{l}\text { No. 277: The Developmental Consequences of } \\
\text { Foreign Direct Investment in the Transition } \\
\text { from Socialism to Capitalism: The } \\
\text { Performance of Foreign Owned Firms in } \\
\text { Hungary }\end{array}$ & Lawrence Peter King & September 1999 \\
\hline $\begin{array}{l}\text { No. 276: Stability and Disorder: An } \\
\text { Evolutionary Analysis of Russia's Virtual } \\
\text { Economy }\end{array}$ & Clifford Gaddy and Barry W. Ickes & November 1999 \\
\hline $\begin{array}{l}\text { No. 275: Limiting Government Predation } \\
\text { Through Anonymous Banking: A Theory with } \\
\text { Evidence from China. }\end{array}$ & $\begin{array}{l}\text { Chong-En Bai, David D. Li, Yingyi Qian } \\
\text { and Yijiang Wang }\end{array}$ & July 1999 \\
\hline *No. 274: Transition with Labour Supply & Tito Boeri & December 1999 \\
\hline $\begin{array}{l}\text { No. 273: Sectoral Restructuring and Labor } \\
\text { Mobility: A Comparative Look at the Czech } \\
\text { Republic }\end{array}$ & Vit Sorm and Katherine Terrell & November 1999 \\
\hline $\begin{array}{l}\text { *No. 272: Published in: Journal of } \\
\text { Comparative Economics "Returns to Human } \\
\text { Capital Under the Communist Wage Grid and } \\
\text { During the Transition to a Market Economy" } \\
\text { Vol. 27, pp. 33-60 1999. }\end{array}$ & $\begin{array}{l}\text { Daniel Munich, Jan Svejnar and Katherine } \\
\text { Terrell }\end{array}$ & October 1999 \\
\hline $\begin{array}{l}\text { No. 271: Barter in Russia: Liquidity Shortage } \\
\text { Versus Lack of Restructuring }\end{array}$ & Sophie Brana and Mathilde Maurel & June 1999 \\
\hline $\begin{array}{l}\text { No. 270: Tests for Efficient Financial } \\
\text { Intermediation with Application to China }\end{array}$ & Albert Park and Kaja Sehrt & March 1999 \\
\hline $\begin{array}{l}\text { No. } 269 \text { a: Russian Privatization and } \\
\text { Corporate Governance: What Went Wrong? }\end{array}$ & $\begin{array}{l}\text { Bernard Black, Reinier Kraakman and } \\
\text { Anna Tarassova }\end{array}$ & May 2000 \\
\hline $\begin{array}{l}\text { No. 269: Russian Privatization and Corporate } \\
\text { Governance: What Went Wrong? }\end{array}$ & $\begin{array}{l}\text { Bernard Black, Reinier Kraakman and } \\
\text { Anna Tarassova }\end{array}$ & September 1999 \\
\hline $\begin{array}{l}\text { No. 268: Are Russians Really Ready for } \\
\text { Capitalism? }\end{array}$ & Susan Linz & September 1999 \\
\hline $\begin{array}{l}\text { No. 267: Do Stock Markets Promote } \\
\text { Economic Growth? }\end{array}$ & $\begin{array}{l}\text { Randall K. Filer, Jan Hanousek and Nauro } \\
\text { Campos }\end{array}$ & September 1999 \\
\hline $\begin{array}{l}\text { No. 266: Objectivity, Proximity and } \\
\text { Adaptability in Corporate Governance }\end{array}$ & Arnoud W.A Boot and Jonathan R. Macey & September 1999 \\
\hline $\begin{array}{l}\text { No. 265: When the Future is not What it Used } \\
\text { to Be: Lessons from the Western European } \\
\text { Experience to Forecasting Education and } \\
\text { Training in Transitional Economies }\end{array}$ & $\begin{array}{l}\text { Nauro F. Campos, Gerard Hughes, Stepan } \\
\text { Jurajda, and Daniel Munich }\end{array}$ & September 1999 \\
\hline $\begin{array}{l}\text { No. 264: The Institutional Foundation of } \\
\text { Foreign-Invested Enterprises (FIEs) in China }\end{array}$ & Yasheng Huang & September 1999 \\
\hline $\begin{array}{l}\text { No. 263: The Changing Corporate } \\
\text { Governance Paradigm: Implications for } \\
\text { Transition and Developing Countries }\end{array}$ & $\begin{array}{l}\text { Erik Berglof and Ernst-Ludwig von } \\
\text { Thadden }\end{array}$ & June 1999 \\
\hline No. 262: Law Enforcement and Transition & Gerard Roland and Thierry Verdier & May 1999 \\
\hline $\begin{array}{l}\text { No. 261: Soft Budget Constraints, Pecuniary } \\
\text { Externality, and the Dual Track System }\end{array}$ & Jiahua Che & June 2000 \\
\hline No. 260: Missing Market in Labor Quality: & Gary H. Jefferson & July 1999 \\
\hline
\end{tabular}

Publications denoted by an asterisk are not available on the Kresge Library webpage (http://www.wdi.bus.umich.edu) 


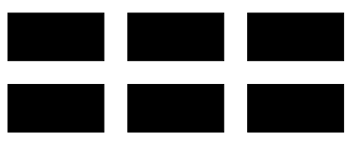

THE WILLIAM DAVIDSON INSTITUTE

AT THE UNIVERSITY OF MICHIGAN BUSINESSSCHOOL

\begin{tabular}{|c|c|c|}
\hline The Role of Quality Markets in Transiton & & \\
\hline $\begin{array}{l}\text { No. 259: Do Corporate Global Environmental } \\
\text { Standards in Emerging Markets Create or } \\
\text { Destroy Market Value }\end{array}$ & $\begin{array}{l}\text { Glen Dowell, Stuart Hart and Bernard } \\
\text { Yeung }\end{array}$ & June 1999 \\
\hline $\begin{array}{l}\text { No. 258: Public Training and Outflows from } \\
\text { Unemployment }\end{array}$ & Patrick A. Puhani & June 1999 \\
\hline $\begin{array}{l}\text { No. 257: Ownership Versus Environment: } \\
\text { Why are Public Sector Firms Ineffecient? }\end{array}$ & Ann P. Bartel and Ann E. Harrison & June 1999 \\
\hline $\begin{array}{l}\text { No. 256: Taxation and Evasion in the } \\
\text { Presence of Exortion by Organized Crime }\end{array}$ & $\begin{array}{l}\text { Michael Alexeev, Eckhard Janeba and } \\
\text { Stefan Osborne }\end{array}$ & November 1999 \\
\hline $\begin{array}{l}\text { No. 255: Revisiting Hungary's Bankruptcy } \\
\text { Episode }\end{array}$ & John P. Bonin and Mark E. Schaffer & September 1999 \\
\hline $\begin{array}{l}\text { No. 254: FDI in Emerging Markets: A Home- } \\
\text { Country View }\end{array}$ & Marina v.N Whitman & June 1999 \\
\hline $\begin{array}{l}\text { No. 253: The Asian Financial Crisis: What } \\
\text { Happened, and What is to be Done }\end{array}$ & Jeffrey D. Sachs and Wing Thye Woo & January 1999 \\
\hline $\begin{array}{l}\text { No. 252: Organizational Law as Asset } \\
\text { Partitioning }\end{array}$ & Henry Hansmann and Reinier Kraakman & September 1999 \\
\hline $\begin{array}{l}\text { No. 251: Consumer Behavior Research in } \\
\text { Emerging Consumer Markets: the Case of the } \\
\text { Optimum Stimulation Level in South Africa }\end{array}$ & $\begin{array}{l}\text { Jan-Benedict E. M. Steenkamp and Steven } \\
\text { M. Burgess }\end{array}$ & September 1999 \\
\hline $\begin{array}{l}\text { No. 250: Property Rights Formation and the } \\
\text { Organization of Exchange and Production in } \\
\text { Rural China }\end{array}$ & $\begin{array}{l}\text { Matthew A. Turner, Loren Brandt, and } \\
\text { Scott Rozelle }\end{array}$ & July 1998 \\
\hline $\begin{array}{l}\text { No. 249: Impacts of the Indonesian Economic } \\
\text { Crisis: Price Changes and the Poor }\end{array}$ & $\begin{array}{l}\text { James Levinsohn, Steven Berry, and Jed } \\
\text { Friedman }\end{array}$ & June 1999 \\
\hline $\begin{array}{l}\text { No. 248: Internal Barriers in the Transition of } \\
\text { Enterprises from Central Plan to Market }\end{array}$ & Charalambos Vlachoutsicos & July 1999 \\
\hline $\begin{array}{l}\text { No. 247: Spillovers from Multinationals in } \\
\text { Developing Countries: the Mechanisms at } \\
\text { Work }\end{array}$ & Richard E. Caves & June 1999 \\
\hline $\begin{array}{l}\text { No. 246: Dynamism and Inertia on the } \\
\text { Russian Labour Market: A Model of } \\
\text { Segmentation }\end{array}$ & $\begin{array}{l}\text { Irena Grosfeld, Claudia Senik-Leygonie, } \\
\text { Thierry Verdier, Stanislav Kolenikov and } \\
\text { Elena Paltseva }\end{array}$ & May 1999 \\
\hline $\begin{array}{l}\text { No. 245: Lessons from Bank Privatization in } \\
\text { Central Europe }\end{array}$ & John Bonin and Paul Wachtel & May 1999 \\
\hline $\begin{array}{l}\text { No. 244: Nominal-Real Tradeoffs and the } \\
\text { Effects of Monetary Policy: the Romanian } \\
\text { Experience }\end{array}$ & Christian Popa & December 1998 \\
\hline $\begin{array}{l}\text { No. 243: Privatization, Political Risk and } \\
\text { Stock Market Development in Emerging } \\
\text { Economies }\end{array}$ & Enrico C. Perotti and Pieter van Oijen & March 1999 \\
\hline $\begin{array}{l}\text { No. 242: Investment Financing in Russian } \\
\text { Financial-Industrial Groups }\end{array}$ & Enrico C. Perotti and Stanislav Gelfer & October 1998 \\
\hline $\begin{array}{l}\text { No. 241: Can governments maintain hard } \\
\text { budget constraints? Bank lending and } \\
\text { financial isolation in Romania }\end{array}$ & $\begin{array}{l}\text { Octavian Carare, Constantijn Claessens, } \\
\text { Enrico C. Perotti }\end{array}$ & January 1999 \\
\hline $\begin{array}{l}\text { No. 240: Democratic Institutions and } \\
\text { Economic Reform: the Polish Case }\end{array}$ & $\begin{array}{l}\text { John E. Jackson, Jacek Klich, and } \\
\text { Krystyna Poznanska }\end{array}$ & April 1998 \\
\hline $\begin{array}{l}\text { No. 239: A Longitudinal Study of IJV } \\
\text { Performance in Eastern Europe }\end{array}$ & Keith D. Brouthers and Gary Bamossy & June 1999 \\
\hline
\end{tabular}

Publications denoted by an asterisk are not available on the Kresge Library webpage (http://www.wdi.bus.umich.edu) 


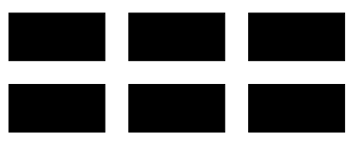

THE WILLIAM DAVIDSON INSTITUTE

AT THE UNIVERSITY OF MICHIGAN BUSINESSSCHOOL

\begin{tabular}{|c|c|c|}
\hline $\begin{array}{l}\text { No. 238: Published in: Journal of Business } \\
\text { Venturing, "Firm Creation and Economic } \\
\text { Transitions" Vol. 14, Iss. 5,6 Sep/Nov 1999, } \\
\text { pp. 427-450. }\end{array}$ & $\begin{array}{l}\text { John E. Jackson, Jacek Klich, Krystyna } \\
\text { Poznanska }\end{array}$ & July 1998 \\
\hline $\begin{array}{l}\text { No. 237: Analysis of Entrepreneurial Attitudes } \\
\text { in Poland }\end{array}$ & $\begin{array}{l}\text { John E. Jackson and Aleksander S. } \\
\text { Marcinkowski }\end{array}$ & March 1997 \\
\hline $\begin{array}{l}\text { No. 236: Investment and Finance in De Novo } \\
\text { Private Firms: Empirical Results from the } \\
\text { Czech Republic, Hungary, and Poland }\end{array}$ & $\begin{array}{l}\text { Andrzej Bratkowski, Irena Grosfeld, Jacek } \\
\text { Rostowski }\end{array}$ & April 1999 \\
\hline $\begin{array}{l}\text { No. 235: Does a Soft Macroeconomic } \\
\text { Environment Induce Restructuring on the } \\
\text { Microeconomic Level during the Transition } \\
\text { Period? Evidence from Investment Behavior } \\
\text { of Czech Enterprises }\end{array}$ & Lubomír Lizal & June 1999 \\
\hline $\begin{array}{l}\text { No. 234: Banking Reform in China: Gradually } \\
\text { Strengthening Pillar or Fragile Reed? }\end{array}$ & John Bonin & June 1999 \\
\hline $\begin{array}{l}\text { No. 233: Theories of Soft Budget Constraints } \\
\text { and the Analysis of Banking Crises }\end{array}$ & Janet Mitchell & March 1999 \\
\hline $\begin{array}{l}\text { No. 232: Unemployment Risk, Precautionary } \\
\text { Savings, and Moonlighting in Russia }\end{array}$ & $\begin{array}{l}\text { Alessandra Guariglia and Byung-Yeon } \\
\text { Kim }\end{array}$ & June 1999 \\
\hline $\begin{array}{l}\text { No. 231: Investing in Turbulent Times: The } \\
\text { Investment Behavior of Polish Firms in the } \\
\text { Transition }\end{array}$ & $\begin{array}{l}\text { Josef C. Brada, Arthur E. King, and Chia- } \\
\text { Ying Ma }\end{array}$ & April 1999 \\
\hline $\begin{array}{l}\text { No. 230: The End of Moderate Inflation in } \\
\text { Three Transition Economies? }\end{array}$ & Josef C. Brada and Ali M. Kutan & April 1999 \\
\hline $\begin{array}{l}\text { No. 229: Back to the Future: The Growth } \\
\text { Prospects of Transition Economies } \\
\text { Reconsidered }\end{array}$ & Nauro F. Campos & April 1999 \\
\hline $\begin{array}{l}\text { No. 228: The Enterprise Isolation Program in } \\
\text { Russia }\end{array}$ & Simeon Djankov & April 1999 \\
\hline $\begin{array}{l}\text { No. 227: Published in: Journal of } \\
\text { Comparative Economics, "Ownership } \\
\text { Concentration and Corporate Performance in } \\
\text { the Czech Republic" 27(3), September 1999, } \\
\text { pp. 498-513. }\end{array}$ & Stijn Claessens and Simeon Djankov & April 1999 \\
\hline $\begin{array}{l}\text { No. 226: Unemployment Benefit Entitlement } \\
\text { and Training Effects in Poland during } \\
\text { Transition }\end{array}$ & Patrick A. Puhani & March 1999 \\
\hline $\begin{array}{l}\text { No. 225: Transition at Whirlpool-Tatramat: } \\
\text { Case Studies }\end{array}$ & Hans Brechbuhl and Sonia Ferencikova & March 1999 \\
\hline $\begin{array}{l}\text { No. 224: Measuring Progress in Transition } \\
\text { and Towards EU Accession: A Comparison of } \\
\text { Manufacturing Firms in Poland, Romania, } \\
\text { and Spain }\end{array}$ & $\begin{array}{l}\text { Wendy Carlin, Saul Estrin, and Mark } \\
\text { Schaffer }\end{array}$ & March 1999 \\
\hline $\begin{array}{l}\text { No. 223: Product Market Competition in } \\
\text { Transition Economies: Increasing Varieties } \\
\text { and Consumer Loyalty }\end{array}$ & Mitsutoshi M. Adachi & March 1999 \\
\hline $\begin{array}{l}\text { No. 222: Opaque Markets and Rapid Growth: } \\
\text { the Superiority of Bank-Centered Financial } \\
\text { Systems for Developing Nations }\end{array}$ & Rodney Wallace & July 1999 \\
\hline $\begin{array}{l}\text { No. 221: Technology Spillovers through } \\
\text { Foreign Direct Investment }\end{array}$ & Yuko Kinoshita & January 1999 \\
\hline
\end{tabular}

Publications denoted by an asterisk are not available on the Kresge Library webpage (http://www.wdi.bus.umich.edu) 


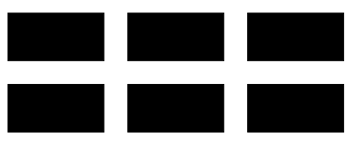

THE WILLIAM DAVIDSON INSTITUTE

AT THE UNIVERSITY OF MICHIGAN BUSINESSSCHOOL

\begin{tabular}{|c|c|c|}
\hline $\begin{array}{l}\text { No. 220: Managerial, Expertise and Team } \\
\text { Centered Forms of Organizing: A Cross- } \\
\text { Cultural Exploration of Independence in } \\
\text { Engineering Work }\end{array}$ & Leslie Perlow & January 1999 \\
\hline $\begin{array}{l}\text { No. 219: Household Structure and Labor } \\
\text { Demand in Agriculture: Testing for } \\
\text { Separability in Rural China }\end{array}$ & Audra J. Bowlus and Terry Sicular & January 1999 \\
\hline $\begin{array}{l}\text { No. 218: Competing Strategies of FDI and } \\
\text { Technology Transfer to China: American and } \\
\text { Japanese Firms }\end{array}$ & W. Mark Fruin and Penelope Prime & January 1999 \\
\hline $\begin{array}{l}\text { No. } 217 \text { Published in: Journal of } \\
\text { Comparative Economics, "Returns to } \\
\text { Mobility in the Transition to a Market } \\
\text { Economy" Vol. 27, No. 1, March 1999, pp. 4- }\end{array}$ & Tito Boeri and Christopher J. Flinn & January 1999 \\
\hline $\begin{array}{l}\text { No. } 216 \text { Published in: Journal of } \\
\text { Comparative Economics, "Labor Market } \\
\text { Policies and Unemployment in the Czech } \\
\text { Republic." Vol. 27, No. 1, March 1999, pp. } \\
\text { 33-60. }\end{array}$ & Katherine Terrell and Vit Sorm & November 1998 \\
\hline $\begin{array}{l}\text { No. } 215 \text { Published in: Journal of } \\
\text { Comparative Economics, "Active Labor } \\
\text { Market Policies in Poland: Human Capital } \\
\text { Enhancement, Stigmatization or Benefit } \\
\text { Churning?" Vol. 27, No. 1, March 1999, pp. } \\
61-\end{array}$ & $\begin{array}{l}\text { Jochen Kluve, Hartmut Lehmann, and } \\
\text { Christoph M. Schmidt }\end{array}$ & December 1998 \\
\hline $\begin{array}{l}\text { No. } 214 \text { Published in: Journal of } \\
\text { Comparative Economics, "Does the Slovenian } \\
\text { Public Work Program Increase Participants' } \\
\text { Chances to Find a Job?" Vol. 27, No.1, } \\
\text { March 1999, pp. 113- }\end{array}$ & Milan Vodopivec & December 1998 \\
\hline $\begin{array}{l}\text { No. } 213 \text { Published in: Journal of } \\
\text { Comparative Economics, "Effects of Active } \\
\text { Labor Market Programs on the Transition } \\
\text { Rate from Unemployment into Regular Jobs in } \\
\text { the Slovak Republic." Vol. 27, No. 1, March } \\
\text { 1999, pp. 90- }\end{array}$ & Martina Lubyova and Jan C. van Ours & December 1998 \\
\hline $\begin{array}{l}\text { No. 212: The Marketing System in Bulgarian } \\
\text { Livestock Production - The Present State and } \\
\text { Evolutionary Processes During the Period of } \\
\text { Economic Transition }\end{array}$ & Yordan Staykov, Team Leader & October 1998 \\
\hline $\begin{array}{l}\text { No. 211: Bankruptcy Experience in Hungary } \\
\text { and the Czech Republic }\end{array}$ & Janet Mitchell & October 1998 \\
\hline $\begin{array}{l}\text { No 210: Values, Optimum Stimulation Levels } \\
\text { and Brand Loyalty: New Scales in New } \\
\text { Populations }\end{array}$ & Steven M. Burgess and Mari Harris & September 1998 \\
\hline $\begin{array}{l}\text { No. 209: Inherited Wealth, Corporate Control } \\
\text { and Economic Growth }\end{array}$ & $\begin{array}{l}\text { Randall K. Morck, David A. Stangeland, } \\
\text { and Bernard Yeung }\end{array}$ & September 1998 \\
\hline $\begin{array}{l}\text { No. 208: A Cultural Analysis of Homosocial } \\
\text { Reproduction and Contesting Claims to } \\
\text { Competence in Transitional Firms }\end{array}$ & Michael D. Kennedy & July 1998 \\
\hline $\begin{array}{l}\text { No. 207: From Survival to Success: The } \\
\text { Journey of Corporate Transformation at }\end{array}$ & Arthur Yeung and Kenneth DeWoskin & July 1998 \\
\hline
\end{tabular}

Publications denoted by an asterisk are not available on the Kresge Library webpage (http://www.wdi.bus.umich.edu) 


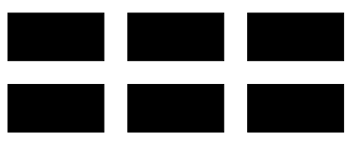

THE WILLIAM DAVIDSON INSTITUTE

AT THE UNIVERSITY OF MICHIGAN BUSINESSSCHOOL

\begin{tabular}{|c|c|c|}
\hline $\begin{array}{l}\text { Haier. Forthcoming in Teaching the } \\
\text { Dinosaurs to Dance: Organizational Change } \\
\text { in Transition Economies ed. Daniel Denison. } \\
\text { No. 206: Why Do People Work If They Are } \\
\text { Not Paid? An Example from Eastern Europe. } \\
\text { Forthcoming in Teaching the Dinosaurs to } \\
\text { Dance: Organizational Change in Transition } \\
\text { Economies ed. Daniel Denison. }\end{array}$ & Irina L. Zinovieva & May 1998 \\
\hline $\begin{array}{l}\text { No. 205: Firm Ownership and Work } \\
\text { Motivation in Bulgaria and Hungary: An } \\
\text { Empirical Study of the Transition in the Mid- } \\
\text { 1990s. Forthcoming in Teaching the } \\
\text { Dinosaurs to Dance: Organizational Change } \\
\text { in Transition Economies ed. Daniel Denison. }\end{array}$ & $\begin{array}{l}\text { Robert A. Roe, Irina L. Zinovieva, } \\
\text { Elizabeth Dienes, and Laurens A. ten Horn }\end{array}$ & May 1998 \\
\hline $\begin{array}{l}\text { No. 204: Human Resource Management in the } \\
\text { Restructuring of Chinese Joint Ventures. } \\
\text { Forthcoming in Teaching the Dinosaurs to } \\
\text { Dance: Organizational Change in Transition } \\
\text { Economies ed. Daniel Denison. }\end{array}$ & Nandani Lynton & April 1998 \\
\hline $\begin{array}{l}\text { No. 203: Emergent Compensation Strategies } \\
\text { in Post-Socialist Poland: Understanding the } \\
\text { Cognitive Underpinnings of Management } \\
\text { Practices in a Transition Economy. } \\
\text { Forthcoming in Teaching the Dinosaurs to } \\
\text { Dance: Organizational Change in Transition } \\
\text { Economies ed. Daniel Denison. }\end{array}$ & Marc Weinstein & March 1998 \\
\hline $\begin{array}{l}\text { No. 202: Corporate Transformation and } \\
\text { Organizational Learning: The People's } \\
\text { Republic of China. Forthcoming in Teaching } \\
\text { the Dinosaurs to Dance: Organizational } \\
\text { Change in Transition Economies ed. Daniel } \\
\text { Denison. }\end{array}$ & Meinolf Dierkes and Zhang Xinhua & March 1998 \\
\hline $\begin{array}{l}\text { No. 201: Foreign Direct Investment as a } \\
\text { Factor of Change: The Case of Slovakia. } \\
\text { Forthcoming in Teaching the Dinosaurs to } \\
\text { Dance: Organizational Change in Transition } \\
\text { Economies ed. Daniel Denison. }\end{array}$ & Sonia Ferencikova & February 1998 \\
\hline $\begin{array}{l}\text { No. 200: Radical versus Incremental Change: } \\
\text { The Role of Capabilities, Competition, and } \\
\text { Leaders. Forthcoming in Teaching the } \\
\text { Dinosaurs to Dance: Organizational Change } \\
\text { in Transition Economies ed. Daniel Denison. }\end{array}$ & Karen L. Newman & February 1998 \\
\hline $\begin{array}{l}\text { No. 199: The Emergence of Market Practices } \\
\text { in China's Economic Transition: Price Setting } \\
\text { Practices in Shanghai's Industrial Firms. } \\
\text { Forthcoming in Teaching the Dinosaurs to } \\
\text { Dance: Organizational Change in Transition } \\
\text { Economies ed. Daniel Denison. }\end{array}$ & Douglas Guthrie & February 1998 \\
\hline $\begin{array}{l}\text { No. 198: The Application of Change } \\
\text { Management Methods at Business } \\
\text { Organizations Operating in Hungary: } \\
\text { Challenges in the Business and Cultural }\end{array}$ & Dr. János Fehér & January 1998 \\
\hline
\end{tabular}

Publications denoted by an asterisk are not available on the Kresge Library webpage (http://www.wdi.bus.umich.edu) 


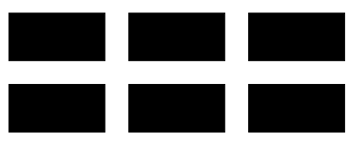

THE WILLIAM DAVIDSON INSTITUTE

AT THE UNIVERSITY OF MICHIGAN BUSINESSSCHOOL

\begin{tabular}{|c|c|c|}
\hline $\begin{array}{l}\text { Environment and First Practical Experiences. } \\
\text { Forthcoming in Teaching the Dinosaurs to } \\
\text { Dance: Organizational Change in Transition } \\
\text { Economies ed. Daniel Denison. }\end{array}$ & & \\
\hline $\begin{array}{l}\text { No. 197: Organizational Changes in Russian } \\
\text { Industrial Enterprises: Mutation of Decision- } \\
\text { Making Structures and Transformations of } \\
\text { Ownership. Forthcoming in Teaching the } \\
\text { Dinosaurs to Dance: Organizational Change } \\
\text { in Transition Economies ed. Daniel Denison. }\end{array}$ & Igor B. Gurkov & January 1998 \\
\hline $\begin{array}{l}\text { No. 196: Understanding and Managing } \\
\text { Challenges to the Romanian Companies } \\
\text { during Transition. Forthcoming in Teaching } \\
\text { the Dinosaurs to Dance: Organizational } \\
\text { Change in Transition Economies ed. Daniel } \\
\text { Denison. }\end{array}$ & Dan Candea and Rodica M. Candea & January 1998 \\
\hline $\begin{array}{l}\text { No. 195: Insider Lending and Economic } \\
\text { Transition: The Structure, Function, and } \\
\text { Performance Impact of Finance Companies in } \\
\text { Chinese Business Groups. Forthcoming in } \\
\text { Teaching the Dinosaurs to Dance: } \\
\text { Organizational Change in Transition } \\
\text { Economies ed. Daniel Denison. }\end{array}$ & Lisa A. Keister & December 1997 \\
\hline $\begin{array}{l}\text { No. 194: Japanese Investment in Transitional } \\
\text { Economies: Characteristics and Performance. } \\
\text { Forthcoming in Teaching the Dinosaurs to } \\
\text { Dance: Organizational Change in Transition } \\
\text { Economies ed. Daniel Denison. }\end{array}$ & Paul W. Beamish and Andrew Delios & November 1997 \\
\hline $\begin{array}{l}\text { No. 193: Building Successful Companies in } \\
\text { Transition Economies. Forthcoming in } \\
\text { Teaching the Dinosaurs to Dance: } \\
\text { Organizational Change in Transition } \\
\text { Economies ed. Daniel Denison. }\end{array}$ & Dr. Ivan Perlaki & January 1998 \\
\hline $\begin{array}{l}\text { No. 192: Russian Communitariansim: An } \\
\text { Invisible Fist in the Transformation Process of } \\
\text { Russia. Forthcoming in Teaching the } \\
\text { Dinosaurs to Dance: Organizational Change } \\
\text { in Transition Economies ed. Daniel Denison. }\end{array}$ & Charalambos Vlachoutsicos & July 1998 \\
\hline No. 191: Teaching the Dinosaurs to Dance & Michal Cakrt & September 1997 \\
\hline $\begin{array}{l}\text { No. 190: Strategic Restructuring: Making } \\
\text { Capitalism in Post-Communist Eastern } \\
\text { Europe. Forthcoming in Teaching the } \\
\text { Dinosaurs to Dance: Organizational Change } \\
\text { in Transition Economies ed. Daniel Denison. }\end{array}$ & Lawrence P. King & September 1997 \\
\hline $\begin{array}{l}\text { No. 189: Published in: Regional Science and } \\
\text { Urban Economics, "Russia's Internal } \\
\text { Border", } 29 \text { (5), September 1999. }\end{array}$ & Daniel Berkowitz and David N. DeJong & July 1998 \\
\hline $\begin{array}{l}\text { No. 187: Corporate Structure and } \\
\text { Performance in Hungary }\end{array}$ & László Halpern and Gábor Kórsöi & July 1998 \\
\hline $\begin{array}{l}\text { No. 186: Performance of Czech Companies by } \\
\text { Ownership Structure }\end{array}$ & Andrew Weiss and Georgiy Nikitin & June 1998 \\
\hline No. 185: Firm Performance in Bulgaria and & Jozef Konings & July 1998 \\
\hline
\end{tabular}

Publications denoted by an asterisk are not available on the Kresge Library webpage (http://www.wdi.bus.umich.edu) 


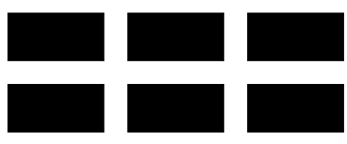

THE WILLIAM DAVIDSON INSTITUTE

AT THE UNIVERSITY OF MICHIGAN BUSINESSSCHOOL

\begin{tabular}{|c|c|c|}
\hline $\begin{array}{l}\text { Estonia: The effects of competitive pressure, } \\
\text { financial pressure and disorganisation }\end{array}$ & & \\
\hline $\begin{array}{l}\text { No. 184: Investment and Wages during the } \\
\text { Transition: Evidence from Slovene Firms }\end{array}$ & Janez Prasnikar and Jan Svejnar & July 1998 \\
\hline $\begin{array}{l}\text { No. 183: Investment Portfolio under Soft } \\
\text { Budget: Implications for Growth, Volatility } \\
\text { and Savings }\end{array}$ & Chongen Bai and Yijiang Wang & \\
\hline $\begin{array}{l}\text { No. 181: Delegation and Delay in Bank } \\
\text { Privatization }\end{array}$ & Loránd Ambrus-Lakatos and Ulrich Hege & July 1998 \\
\hline $\begin{array}{l}\text { No. 180: Financing Mechanisms and } R \& D \\
\text { Investment }\end{array}$ & Haizhou Huang and Chenggang Xu & July 1998 \\
\hline $\begin{array}{l}\text { No. 179: Organizational Culture and } \\
\text { Effectiveness: The Case of Foreign Firms in } \\
\text { Russia }\end{array}$ & Carl F. Fey and Daniel R. Denison & January 1999 \\
\hline $\begin{array}{l}\text { No. 178: Output and Unemployment } \\
\text { Dynamics in Transition }\end{array}$ & Vivek H. Dehejia and Douglas W. Dwyer & January 1998 \\
\hline $\begin{array}{l}\text { No. 177: Published in: Economics of } \\
\text { Transition,, “Bureaucracies in the Russian } \\
\text { Voucher Privatization" Vol. 8, No. 1, 2000, } \\
\text { pp. 37-57. }\end{array}$ & Guido Friebel & June 1998 \\
\hline $\begin{array}{l}\text { No. 176: Chronic Moderate Inflation in } \\
\text { Transition: The Tale of Hungary }\end{array}$ & János Vincze & June 1998 \\
\hline $\begin{array}{l}\text { No. 175: Privatisation and Market Structure } \\
\text { in a Transition Economy }\end{array}$ & John Bennett and James Maw & June 1998 \\
\hline $\begin{array}{l}\text { No. 174: Ownership and Managerial } \\
\text { Competition: Employee, Customer, or Outside } \\
\text { Ownership }\end{array}$ & Patrick Bolton and Chenggang Xu & June 1998 \\
\hline $\begin{array}{l}\text { No. 173: Intragovernment Procurement of } \\
\text { Local Public Good: A Theory of } \\
\text { Decentralization in Nondemocratic } \\
\text { Government }\end{array}$ & Chong-en Bai, Yu Pan and Yijiang Wang & June 1998 \\
\hline $\begin{array}{l}\text { No. 172: Political Instability and Growth in } \\
\text { Proprietary Economies }\end{array}$ & Jody Overland and Michael Spagat & August 1998 \\
\hline $\begin{array}{l}\text { No. 171: Published in Post-Communist } \\
\text { Economies, "Framework Issues in the } \\
\text { Privatization Strategies of the Czech Republic, } \\
\text { Hungary, and Poland" Vol. 11, no. 1 March } \\
\text { 1999. }\end{array}$ & Morris Bornstein & June 1998 \\
\hline $\begin{array}{l}\text { No. 170: Published in: European Journal of } \\
\text { Political Economy "Privatization, Ownership } \\
\text { Structure and Transparency: How to Measure } \\
\text { a Real Involvement of the State” 15(4), } \\
\text { November 1999, pp. 605-18. }\end{array}$ & Frantisek Turnovec & May 1998 \\
\hline $\begin{array}{l}\text { No. } 169 \text { Published in: American Economic } \\
\text { Review, “Unemployment and the Social Safety } \\
\text { Net during Transitions to a Market Economy: } \\
\text { Evidence from Czech and Slovak Men.”Vol. } \\
\text { 88, No. 5, Dec. 1998, pp. 1117-1142. }\end{array}$ & $\begin{array}{l}\text { John C. Ham, Jan Svejnar, and Katherine } \\
\text { Terrell }\end{array}$ & December 1998 \\
\hline $\begin{array}{l}\text { No. 167: Voucher Privatization with } \\
\text { Investment Funds: An Institutional Analysis }\end{array}$ & David Ellerman & March 1998 \\
\hline $\begin{array}{l}\text { No. 166: Published in: Marketing Issues in } \\
\text { Transitional Economies, "Value Priorities }\end{array}$ & $\begin{array}{l}\text { Steven M. Burgess and Jan-Benedict E.M. } \\
\text { Steenkamp }\end{array}$ & August 1998 \\
\hline
\end{tabular}

Publications denoted by an asterisk are not available on the Kresge Library webpage (http://www.wdi.bus.umich.edu) 


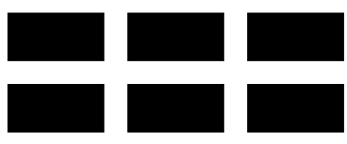

THE WILLIAM DAVIDSON INSTITUTE

AT THE UNIVERSITY OF MICHIGAN BUSINESSSCHOOL

\begin{tabular}{|c|c|c|}
\hline $\begin{array}{l}\text { and Consumer Behavior in a Transitional } \\
\text { Economy: The Case of South Africa” ed. } \\
\text { Rajeev Batra. }\end{array}$ & & \\
\hline $\begin{array}{l}\text { No. 164: Finance and Investment in } \\
\text { Transition: Czech Enterprises, 1993-1994 }\end{array}$ & Ronald Anderson and Chantal Kegels & September 1997 \\
\hline $\begin{array}{l}\text { No. 163: European Union Trade and } \\
\text { Investment Flows U-Shaping Industrial } \\
\text { Output in Central and Eastern Europe: } \\
\text { Theory and Evidence }\end{array}$ & Alexander Repkine and Patrick P. Walsh & April 1998 \\
\hline $\begin{array}{l}\text { No. 162: Skill Acquisition and Private Firm } \\
\text { Creation in Transition Economies }\end{array}$ & Zuzana Brixiova and Wenli $\mathrm{Li}$ & October 1999 \\
\hline No. 161: Corruption in Transition & Susanto Basu and David D. Li & May 1998 \\
\hline $\begin{array}{l}\text { No. 160a: Tenures that Shook the World: } \\
\text { Worker Turnover in Russia, Poland and } \\
\text { Britain }\end{array}$ & $\begin{array}{l}\text { Hartmut Lehmann and Jonathan } \\
\text { Wadsworth }\end{array}$ & November 1999 \\
\hline $\begin{array}{l}\text { No. 160: Tenures that Shook the World: } \\
\text { Worker Turnover in the Russian Federation } \\
\text { and Poland }\end{array}$ & $\begin{array}{l}\text { Hartmut Lehmann and Jonathan } \\
\text { Wadsworth }\end{array}$ & June 1998 \\
\hline $\begin{array}{l}\text { No. 159: Does Market Structure Matter? New } \\
\text { Evidence from Russia }\end{array}$ & Annette N. Brown and J. David Brown & June 1998 \\
\hline $\begin{array}{l}\text { No. 158: Structural Adjustment and Regional } \\
\text { Long Term Unemployment in Poland }\end{array}$ & Hartmut Lehmann and Patrick P. Walsh & June 1997 \\
\hline $\begin{array}{l}\text { No. 157: Baby Boom or Bust? Changing } \\
\text { Fertility in Post-Communist Czech Republic } \\
\text { and Slovakia }\end{array}$ & Robert S. Chase & April 1998 \\
\hline $\begin{array}{l}\text { No. } 156 \text { Published in: Leadership and } \\
\text { Organization Development Journal, } \\
\text { "Leading Radical Change in Transition } \\
\text { Economies." Vol. 19, No. 6, 1998, pp. 309- } \\
324 .\end{array}$ & Karen L. Newman & June 1998 \\
\hline $\begin{array}{l}\text { No. } 155 \text { Published in: Oxford Review of } \\
\text { Economic Policy, "From Theory into } \\
\text { Practice? Restructuring and Dynamism in } \\
\text { Transition Economies.” Vol. 13, No. 2, } \\
\text { Summer 1997, pp. 77-105. }\end{array}$ & Wendy Carlin and Michael Landesmann & June 1997 \\
\hline $\begin{array}{l}\text { No. 154: The Model and the Reality: } \\
\text { Assessment of Vietnamese SOE Reform- } \\
\text { Implementation at the Firm Level }\end{array}$ & $\begin{array}{l}\text { Edmund Malesky, Vu Thanh Hung, Vu Thi } \\
\text { Dieu Anh, and Nancy K. Napier }\end{array}$ & July 1998 \\
\hline $\begin{array}{l}\text { No. } 153 \text { Published in: Journal of } \\
\text { Comparative Economics, "Causes of the Soft } \\
\text { Budget Constraint: Evidence on Three } \\
\text { Explanations." Vol. 26, No. 1, March 1998, } \\
\text { pp. 104-116. }\end{array}$ & David D. Li and Minsong Liang & March 1998 \\
\hline $\begin{array}{l}\text { No. } 152 \text { Published in: Comparative Economic } \\
\text { Studies, "Enterprise Restructuring in Russia's } \\
\text { Transition Economy: Formal and Informal } \\
\text { Mechanisms." Vol. 40, No. 2, Summer 1998, } \\
\text { pp. 5-52. }\end{array}$ & Susan J. Linz and Gary Krueger & April 1998 \\
\hline $\begin{array}{l}\text { No. 151: Labor Productivity in Transition: A } \\
\text { Regional Analysis of Russian Industry }\end{array}$ & Susan J. Linz & May 1998 \\
\hline $\begin{array}{l}\text { No. 150: Tax Avoidance and the Allocation of } \\
\text { Credit. Forthcoming in Financial Systems in }\end{array}$ & Anna Meyendorff & June 1998 \\
\hline
\end{tabular}

Publications denoted by an asterisk are not available on the Kresge Library webpage (http://www.wdi.bus.umich.edu) 


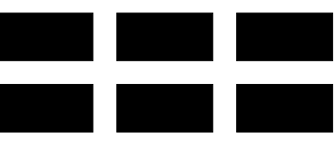

THE WILLIAM DAVIDSON INSTITUTE

AT THE UNIVERSITY OF MICHIGAN BUSINESSSCHOOL

\begin{tabular}{|c|c|c|}
\hline $\begin{array}{l}\text { Transition: The Design of Financial Systems } \\
\text { in Central Europe eds. Anna Meyendorff and } \\
\text { Anjan Thakor. }\end{array}$ & & \\
\hline $\begin{array}{l}\text { No. 149: Commitment, Versatility and } \\
\text { Balance: Determinants of Work Time } \\
\text { Standards and Norms in a Multi-Country } \\
\text { Study of Software Engineers }\end{array}$ & Leslie Perlow and Ron Fortgang & April 1998 \\
\hline $\begin{array}{l}\text { No. 148: Changes in Poland's Transfer } \\
\text { Payments in the 1990s: the Fate of } \\
\text { Pensioners }\end{array}$ & Bozena Leven & June 1998 \\
\hline $\begin{array}{l}\text { No. 147: Environmental Protection and } \\
\text { Economic Development: The Case of the } \\
\text { Huaihe River Basin Cleanup Plan }\end{array}$ & $\begin{array}{l}\text { Robert Letovsky, Reze Ramazani, and } \\
\text { Debra Murphy }\end{array}$ & June 1998 \\
\hline $\begin{array}{l}\text { No. 146: Chief Executive Compensation } \\
\text { During Early Transition: Further Evidence } \\
\text { from Bulgaria }\end{array}$ & $\begin{array}{l}\text { Derek C. Jones, Takao Kato, and Jeffrey } \\
\text { Miller }\end{array}$ & June 1998 \\
\hline $\begin{array}{l}\text { No. } 145 \text { Published in: Economics of } \\
\text { Transition, “Women's Unemployment During } \\
\text { the Transition: Evidence from Czech and } \\
\text { Slovak Micro Data,” Vol. 7, No. 1, May 1999, } \\
\text { pp. 47-78. }\end{array}$ & $\begin{array}{l}\text { John Ham, Jan Svejnar, and Katherine } \\
\text { Terrell }\end{array}$ & May 1998 \\
\hline No. 144: Investment and Wages in Slovenia & Janez Prasnikar & May 1998 \\
\hline $\begin{array}{l}\text { No. } 143 \text { Published in: Review of Financial } \\
\text { Studies, “Optimal Bankruptcy Laws Across } \\
\text { Different Economic Systems,” 12(2), Summer } \\
\text { 1999, pgs. 347-77. }\end{array}$ & Elazar Berkovitch and Ronen Israel & March 1998 \\
\hline $\begin{array}{l}\text { No. 142: Industrial Policy and Poverty in } \\
\text { Transition Economies: Two Steps Forward or } \\
\text { One Step Back? }\end{array}$ & Susan J. Linz & March 1998 \\
\hline $\begin{array}{l}\text { No. 141: Collective Ownership and } \\
\text { Privatization of China's Village Enterprises }\end{array}$ & Suwen Pan and Albert Park & April 1998 \\
\hline $\begin{array}{l}\text { No. 140: A Comparative Look at Labor } \\
\text { Mobility in the Czech Republic: Where have } \\
\text { all the Workers Gone? }\end{array}$ & Vit Sorm and Katherine Terrell & April 1999 \\
\hline $\begin{array}{l}\text { No. 139: The Failure of the Government-Led } \\
\text { Program of Corporate Reorganization in } \\
\text { Romania }\end{array}$ & Simeon Djankov and Kosali Ilayperuma & September 1997 \\
\hline $\begin{array}{l}\text { No. 138: Ownership and Employment in } \\
\text { Russian Industry: 1992-1995 }\end{array}$ & Susan J. Linz & March 1998 \\
\hline $\begin{array}{l}\text { No. } 137 \text { Published in: Journal of Political } \\
\text { Economy, “Reform Without Losers: An } \\
\text { Interpretation of China's Dual-Track } \\
\text { Approach to Transition," Feb. 2000; Vol. 108, } \\
\text { Iss.1; pg. } 120\end{array}$ & $\begin{array}{l}\text { Lawrence J. Lau, Yingyi Qian, and Gerard } \\
\text { Roland }\end{array}$ & November 1997 \\
\hline $\begin{array}{l}\text { No. } 136 \text { Published in: European Economic } \\
\text { Review, "The Political Economy of Mass } \\
\text { Privatization and the Risk of Expropriation," } \\
44(2), \text { February 2000, pgs. 393-421 }\end{array}$ & Klaus M. Schmidt & March 1998 \\
\hline $\begin{array}{l}\text { No. 135: Radical Organizational Change: The } \\
\text { Role of Starting Conditions, Competition, and } \\
\text { Leaders }\end{array}$ & Karen L. Newman & January 1998 \\
\hline No. 134: To Restructure or Not to & Clifford Gaddy and Barry W. Ickes & May 1998 \\
\hline
\end{tabular}

Publications denoted by an asterisk are not available on the Kresge Library webpage (http://www.wdi.bus.umich.edu) 


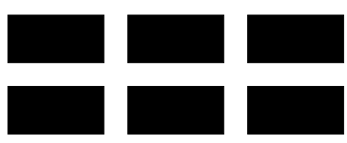

THE WILLIAM DAVIDSON INSTITUTE

AT THE UNIVERSITY OF MICHIGAN BUSINESSSCHOOL

\begin{tabular}{|c|c|c|}
\hline $\begin{array}{l}\text { Restructure: Informal Activities and } \\
\text { Enterprise Behavior in Transition } \\
\text { No. 133: Management 101: Behavior of Firms } \\
\text { in Transition Economies }\end{array}$ & Josef C. Brada & March 1998 \\
\hline $\begin{array}{l}\text { No. } 132 \text { Published in: Quarterly Journal of } \\
\text { Economics, "Interfirm Relationships and } \\
\text { Informal Credit in Vietnam," 114(4), Nov. } \\
\text { 1999, pgs. 1285-1320 }\end{array}$ & John McMillan and Christopher Woodruff & February 1998 \\
\hline $\begin{array}{l}\text { No. } 131 \text { Published in: Comparative Economic } \\
\text { Studies, “Will Restructuring Hungarian } \\
\text { Companies Innovate? An Investigation Based } \\
\text { on Joseph Berliner's Analysis of Innovation in } \\
\text { Soviet Industry.” Vol. 40, No. 2, Summer } \\
\text { 1998, pp. 53-74. }\end{array}$ & John B. Bonin and Istvan Abel & March 1998 \\
\hline $\begin{array}{l}\text { No. 130: Published in The American } \\
\text { Economic Review, "Changing Incentives of } \\
\text { the Chinese Bureaucracy." May, } 1998 .\end{array}$ & David D. Li & January 1998 \\
\hline $\begin{array}{l}\text { No. 129: Restructuring Investment in } \\
\text { Transition: A Model of the Enterprise } \\
\text { Decision }\end{array}$ & Richard E. Ericson & January 1998 \\
\hline $\begin{array}{l}\text { No. } 128 \text { Published in: Comparative Economic } \\
\text { Studies, "Job Rights in Russian Firms: } \\
\text { Endangered or Extinct Institutions?" Vol. 40, } \\
\text { No. 4, Winter 1998, pp. 1-32. }\end{array}$ & Susan J. Linz & January 1998 \\
\hline $\begin{array}{l}\text { No. 127: Accounting for Growth in Post- } \\
\text { Soviet Russia }\end{array}$ & Daniel Berkowitz and David N. DeJong & January 1998 \\
\hline $\begin{array}{l}\text { No. } 126 \text { Published in: Economics of } \\
\text { Transition, "From Federalism, Chinese Style, } \\
\text { to Privatization Chinese Style," 7(1), 1999, } \\
\text { pgs. } 103-31\end{array}$ & $\begin{array}{l}\text { Yuanzheng Cao, Yingyi Qian, and Barry R. } \\
\text { Weingast }\end{array}$ & December 1997 \\
\hline $\begin{array}{l}\text { No. 125: Market Discipline in Conglomerate } \\
\text { Banks: Is an Internal Allocation of Cost of } \\
\text { Capital Necessary as Incentive Device? } \\
\text { Forthcoming in Financial Systems in } \\
\text { Transition: The Design of Financial Systems } \\
\text { in Central Europe eds. Anna Meyendorff and } \\
\text { Anjan Thakor. }\end{array}$ & Arnoud W. A. Boot and Anjolein Schmeits & November 1997 \\
\hline $\begin{array}{l}\text { No. 124: Financial Discipline in the } \\
\text { Enterprise Sector in Transition Countries: } \\
\text { How Does China Compare? }\end{array}$ & Shumei Gao and Mark E. Schaffer & February 1998 \\
\hline $\begin{array}{l}\text { No. 123: Considerations of an Emerging } \\
\text { Marketplace: Managers' Perceptions in the } \\
\text { Southern African Economic Community }\end{array}$ & Brent Chrite and David Hudson & February 1998 \\
\hline $\begin{array}{l}\text { No. 122: A Model of the Informal Economy in } \\
\text { Transition Economies }\end{array}$ & $\begin{array}{l}\text { Simon Commander and Andrei } \\
\text { Tolstopiatenko }\end{array}$ & November 1997 \\
\hline $\begin{array}{l}\text { No. 121: Local Labour Market Dynamics in } \\
\text { the Czech and Slovak Republics }\end{array}$ & Peter Huber and Andreas Worgotter & November 1997 \\
\hline $\begin{array}{l}\text { No. 121: Local Labour Market Dynamics in } \\
\text { the Czech and Slovak Republics }\end{array}$ & Peter Huber and Andreas Worgotter & November 1997 \\
\hline $\begin{array}{l}\text { No. 119: Institutional Upheaval and Company } \\
\text { Transformation in Emerging Market } \\
\text { Economies }\end{array}$ & Karen L. Newman & March 1998 \\
\hline
\end{tabular}

Publications denoted by an asterisk are not available on the Kresge Library webpage (http://www.wdi.bus.umich.edu) 


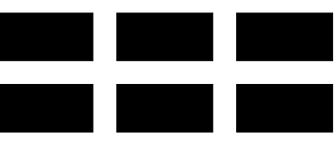

THE WILLIAM DAVIDSON INSTITUTE

AT THE UNIVERSITY OF MICHIGAN BUSINESSSCHOOL

\begin{tabular}{|c|c|c|}
\hline $\begin{array}{l}\text { No. 118: Industrial Decline and Labor } \\
\text { Reallocation in Romania }\end{array}$ & John S. Earle & October 1997 \\
\hline $\begin{array}{l}\text { No. 117: Notes for an Essay on the Soft } \\
\text { Budget Constraint }\end{array}$ & Lorand Ambrus-Lakatos & January 1997 \\
\hline $\begin{array}{l}\text { No. 116: Labor Demand During Transition in } \\
\text { Hungary }\end{array}$ & Gabor Korosi & October 1997 \\
\hline $\begin{array}{l}\text { No. 115: Enterprise Performance and } \\
\text { Managers' Profiles }\end{array}$ & Simeon Djankov and Stijn Claessens & December 1997 \\
\hline $\begin{array}{l}\text { No. } 114 b \text { Employment and Wages in } \\
\text { Enterprises under Communism and in } \\
\text { Transition: Evidence From Central Europe } \\
\text { and Russia }\end{array}$ & Swati Basu, Saul Estrin, and Jan Svejnar & April 2000 \\
\hline $\begin{array}{l}\text { No. 114: Employment and Wage Behavior of } \\
\text { Enterprises in Transitional Economies }\end{array}$ & Swati Basu, Saul Estrin, and Jan Svejnar & October 1997 \\
\hline $\begin{array}{l}\text { No. 113: Preliminary Evidence on Active } \\
\text { Labor Programs' Impact in Hungary and } \\
\text { Poland }\end{array}$ & Christopher J. O'Leary & October 1997 \\
\hline $\begin{array}{l}\text { No. 111: Unemployment Benefits and } \\
\text { Incentives in Hungary: New Evidence }\end{array}$ & Joachim Wolff & October 1997 \\
\hline $\begin{array}{l}\text { No. 110: Published in: Empirical Economics, } \\
\text { "Long-Term Unemployment, Unemployment } \\
\text { Benefits and Social Assistance: The Polish } \\
\text { Experience" Empirical-Economics; 23(1-2), } \\
\text { 1998, pages 55-85. }\end{array}$ & Marek Gora and Christoph M. Schmidt & April 1997 \\
\hline $\begin{array}{l}\text { No. } 109 \text { Published in: Industrial and Labor } \\
\text { Relations Review, "Markets for Communist } \\
\text { Human Capital: Returns to Education and } \\
\text { Experience in Post-Communist Czech } \\
\text { Republic and Slovakia." Vol. 51, No. 3, April } \\
\text { 1998, pp. 401-423. }\end{array}$ & Robert S. Chase & October 1997 \\
\hline $\begin{array}{l}\text { No. 107: The Worker-Firm Matching in the } \\
\text { Transition: (Why) Are the Czechs More } \\
\text { Successful Than Others? }\end{array}$ & $\begin{array}{l}\text { Daniel Münich, Jan Svejnar, and } \\
\text { Katherine Terrell }\end{array}$ & October 1997 \\
\hline $\begin{array}{l}\text { No. } 106 \text { Published in: Journal of } \\
\text { Comparative Economics, “Job Creation, Job } \\
\text { Destruction and Growth of Newly Established, } \\
\text { Privatized and State-Owned Enterprises in } \\
\text { Transition Economies: Survey Evidence from } \\
\text { Bulgaria, Hungary, and Romania," Vol. 26, } \\
\text { No.3, September 1998, pp. 429-445. } \\
\end{array}$ & Valentijn Bilsen and Jozef Konings & September 1998 \\
\hline $\begin{array}{l}\text { No. 105: Getting Behind the East-West } \\
\text { [German] Wage Differential: Theory and } \\
\text { Evidence }\end{array}$ & Michael Burda and Christoph Schmidt & May 1997 \\
\hline $\begin{array}{l}\text { No. 104: The Birth of the "Wage Curve" in } \\
\text { Hungary, 1989-95 }\end{array}$ & Gabor Kertesi and Janos Kollo & October 1997 \\
\hline $\begin{array}{l}\text { No. 103: Published in: Journal of } \\
\text { Comparative Economics, "Grime and } \\
\text { Punishment: Job Insecurity and Wage Arrears } \\
\text { in the Russian Federation" 27, 595-617 } \\
\text { (1999). }\end{array}$ & $\begin{array}{l}\text { Hartmut Lehmann, Jonathan Wadsworth, } \\
\text { and Alessandro Acquisti }\end{array}$ & October 1997 \\
\hline No. 102: Social Networks in Transition & $\begin{array}{l}\text { Lorena Barberia, Simon Johnson, and } \\
\text { Daniel Kaufmann }\end{array}$ & October 1997 \\
\hline
\end{tabular}

Publications denoted by an asterisk are not available on the Kresge Library webpage (http://www.wdi.bus.umich.edu) 


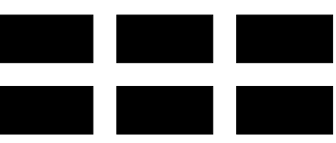

THE WILLIAM DAVIDSON INSTITUTE

AT THE UNIVERSITY OF MICHIGAN BUSINESSSCHOOL

\begin{tabular}{|c|c|c|}
\hline $\begin{array}{l}\text { No. 101: Depreciation and Russian Corporate } \\
\text { Finance: A Pragmatic Approach to Surviving } \\
\text { the Transition }\end{array}$ & Susan J. Linz. & November 1997 \\
\hline No. 100: Romanian Financial System Reform & Anna Meyendorff and Anjan V. Thakor & November 1997 \\
\hline $\begin{array}{l}\text { No. 99: Proceedings of the Conference on } \\
\text { Strategic Alliances in Transitional Economies, } \\
\text { held May 20, } 1997 \text { at the Davidson Institute }\end{array}$ & Edited by Cynthia Koch & May 1997 \\
\hline $\begin{array}{l}\text { No. 98: Institutions, Strain and the } \\
\text { Underground Economy }\end{array}$ & Daniel Daianu and Lucian Albu & November 1997 \\
\hline $\begin{array}{l}\text { No. 97: Structure and Strain in Explaining } \\
\text { Inter-Enterprise Arrears } \\
\text { No. 96: Resource Misallocation and Strain: } \\
\text { Explaining Shocks in Post-Command } \\
\text { Economies }\end{array}$ & $\begin{array}{l}\text { Daniel Daianu } \\
\text { Daniel Daianu }\end{array}$ & $\begin{array}{l}\text { November } 1997 \\
\text { November } 1997\end{array}$ \\
\hline $\begin{array}{l}\text { No. 95: Published in: Finance-a-Uver, } \\
\text { "Czech Money Market: Emerging Links } \\
\text { Among Interest Rates." 48(2) } 1998 \text { pp. } 99- \\
\text { 109. }\end{array}$ & Jan Hanousek and Evzen Kocenda & November 1997 \\
\hline $\begin{array}{l}\text { No. 94: Pre-Reform Industry and the } \\
\text { State Monopsony in China }\end{array}$ & Xiao-Yuan Dong and Louis Putterman & October 1997 \\
\hline $\begin{array}{l}\text { No. 93: China's State-Owned Enterprises } \\
\text { In the First Reform Decade: } \\
\text { An Analysis of a Declining Monopsony }\end{array}$ & Xiao-Yuan Dong and Louis Putterman & October 1997 \\
\hline $\begin{array}{l}\text { No. 92: Expatriate Management in the Czech } \\
\text { Republic }\end{array}$ & Richard B. Peterson & September 1997 \\
\hline $\begin{array}{l}\text { No. 91: China and the Idea of Economic } \\
\text { Reform }\end{array}$ & Thomas G. Rawski & April 1997 \\
\hline $\begin{array}{l}\text { No. } 90 \text { Published in: China Economic } \\
\text { Review, “China's State Enterprise Reform: An } \\
\text { Overseas Perspective.” Vol. 8, Spring 1997, } \\
\text { pp. } 89-98 .\end{array}$ & Thomas G. Rawski & July 1997 \\
\hline $\begin{array}{l}\text { No. 89: The Economic Determinants of } \\
\text { Internal Migration Flows in Russia During } \\
\text { Transition }\end{array}$ & Annette N. Brown & July 1997 \\
\hline $\begin{array}{l}\text { No. 88: Gender Wage Gaps in China's Labor } \\
\text { Market: Size, Structure, Trends }\end{array}$ & $\begin{array}{l}\text { Margaret Maurer-Fazio, Thomas G. } \\
\text { Rawski, and Wei Zhang }\end{array}$ & July 1997 \\
\hline $\begin{array}{l}\text { No. 87: Privatisation in Central and Eastern } \\
\text { Europe }\end{array}$ & Saul Estrin & June 1997 \\
\hline $\begin{array}{l}\text { No. 86: Published in : Economics of } \\
\text { Transition, "The Effect of Privatization on } \\
\text { Wealth Distribution in Russia." v. 7, no. } 2 \text {, } \\
\text { 1999, pp. 449-65 }\end{array}$ & Michael Alexeev & February 1998 \\
\hline $\begin{array}{l}\text { No. 85: Was Privatization in Eastern Germany } \\
\text { a Special Case? Some Lessons from the } \\
\text { Treuhand }\end{array}$ & Uwe Siegmund & September 1997 \\
\hline No. 84: Start-ups and Transition & Daniel M. Berkowitz and David J. Cooper & September 1997 \\
\hline $\begin{array}{l}\text { No. 83: Which Enterprises (Believe They) } \\
\text { Have Soft Budgets after Mass Privatization? } \\
\text { Evidence from Mongolia }\end{array}$ & $\begin{array}{l}\text { James Anderson, Georges Korsun, and } \\
\text { Peter Murrell }\end{array}$ & October 1997 \\
\hline $\begin{array}{l}\text { No. 82: Published in: European Economic } \\
\text { Review, "Unemployment Dynamics and the } \\
\text { Restructuring of the Slovak Unemployment }\end{array}$ & Martina Lubyova and Jan C. van Ours & June 1997 \\
\hline
\end{tabular}

Publications denoted by an asterisk are not available on the Kresge Library webpage (http://www.wdi.bus.umich.edu) 


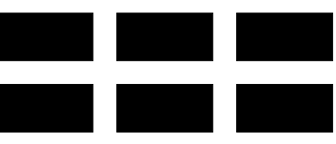

THE WILLIAM DAVIDSON INSTITUTE

AT THE UNIVERSITY OF MICHIGAN BUSINESSSCHOOL

\begin{tabular}{|c|c|c|}
\hline Benefit System.” April, 1997. & & \\
\hline $\begin{array}{l}\text { No. 81: Determinants of Unemployment } \\
\text { Duration in Russia }\end{array}$ & Mark C. Foley & August 1997 \\
\hline $\begin{array}{l}\text { No. 80: The Many Faces of Information } \\
\text { Disclosure }\end{array}$ & Arnoud W.A. Boot and Anjan V. Thakor & October 1997 \\
\hline $\begin{array}{l}\text { No. 79: Published in: Journal of Finance, } \\
\text { "Foreign Speculators and Emerging Equity } \\
\text { Markets."v.22, iss. 2, 2000, pp. 565-613 }\end{array}$ & Geert Bekaert and Campbell R. Harvey & August 1997 \\
\hline $\begin{array}{l}\text { No. 78: The Relationship Between Economic } \\
\text { Factors and Equity Markets in Central Europe }\end{array}$ & Jan Hanousek and Randall K. Filer & June 1997 \\
\hline $\begin{array}{l}\text { No. } 77 \text { Published in: Economics of } \\
\text { Transition, "A Gini Decomposition Analysis } \\
\text { of Inequality in the Czech and Slovak } \\
\text { Republics During the Transition," Vol. 6, } \\
\text { No.1, May 1998, pp. 23-46. }\end{array}$ & Thesia I. Garner and Katherine Terrell & May 1998 \\
\hline $\begin{array}{l}\text { No. 76: Chinese Enterprise Reform as a } \\
\text { Market Process }\end{array}$ & Gary H. Jefferson and Thomas G. Rawski & June 1997 \\
\hline $\begin{array}{l}\text { No. } 75 b: \text { Test of Permanent Income } \\
\text { Hypothesis on Czech Voucher Privatization }\end{array}$ & Jan Hanousek and Zdenek Tima & October 1997 \\
\hline $\begin{array}{l}\text { No. 74: Determinants of Performance of } \\
\text { Manufacturing Firms in Seven European } \\
\text { Transition Economies }\end{array}$ & $\begin{array}{l}\text { Stijn Claessens, Simeon Djankov, and } \\
\text { Gerhard Pohl }\end{array}$ & February 1997 \\
\hline $\begin{array}{l}\text { No. } 73 \text { Published in: Economics of } \\
\text { Transition, "The Restructuring of Large } \\
\text { Firms in Slovak Republic." Vol. 6, No. 1, May } \\
\text { 1998, pp. 67-85 }\end{array}$ & Simeon Djankov and Gerhard Pohl & May 1998 \\
\hline $\begin{array}{l}\text { No. 72: Law, Relationships, and Private } \\
\text { Enforcement: Transactional Strategies of } \\
\text { Russian Enterprises }\end{array}$ & $\begin{array}{l}\text { Kathryn Hendley, Peter Murrell, and } \\
\text { Randi Ryterman }\end{array}$ & November 1998 \\
\hline $\begin{array}{l}\text { No. 71: Giving Credit Where Credit Is Due: } \\
\text { The Changing Role of Rural Financial } \\
\text { Institutions in China }\end{array}$ & Albert Park, Loren Brandt, and John Giles & March 1997 \\
\hline $\begin{array}{l}\text { No. 70: Privatization Versus Competition: } \\
\text { Changing Enterprise Behavior in Russia }\end{array}$ & John S. Earle and Saul Estrin & Spring 1997 \\
\hline $\begin{array}{l}\text { No. 69: Russian Managers under Storm: } \\
\text { Explicit Reality and Implicit Leadership } \\
\text { Theories (A Pilot Exploration) }\end{array}$ & Igor Gurkov & October 1998 \\
\hline $\begin{array}{l}\text { No. 68: The Political Economy of Central- } \\
\text { Local Relations in China: Inflation and } \\
\text { Investment Controls During the Reform Era }\end{array}$ & Yasheng Huang & Spring 1997 \\
\hline $\begin{array}{l}\text { No. 67: Between Two Coordination Failures: } \\
\text { Automotive Industrial Policy in China with a } \\
\text { Comparison to Korea }\end{array}$ & Yasheng Huang & Spring 1997 \\
\hline $\begin{array}{l}\text { No. } 66 \text { Published in: Post-Soviet Geography } \\
\text { and Economics, “Red Executives in Russia's } \\
\text { Transition Economy." Vol. 27, No. 10, } \\
\text { November 1996, pp. 633-651. }\end{array}$ & Susan J. Linz & January 1997 \\
\hline $\begin{array}{l}\text { No. } 65 \text { Published in: Industrial and } \\
\text { Corporate Change, "On the Sequencing of } \\
\text { Privatization in Transition Economies." Vol. } \\
7, \text { No. } 1,1998 .\end{array}$ & Gautam Ahuja and Sumit K. Majumdar & April 1997 \\
\hline No. 64: Published in: Journal of Law and & Pradeep K. Chhibber and Sumit K. & April 1997 \\
\hline
\end{tabular}

Publications denoted by an asterisk are not available on the Kresge Library webpage (http://www.wdi.bus.umich.edu) 


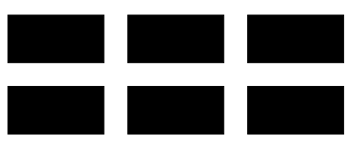

THE WILLIAM DAVIDSON INSTITUTE

AT THE UNIVERSITY OF MICHIGAN BUSINESSSCHOOL

\begin{tabular}{|c|c|c|}
\hline $\begin{array}{l}\text { Economics, "Foreign Ownership and } \\
\text { Profitability: Property Rights, Control and the } \\
\text { Performance of Firms in Indian Industry" } \\
42(1), \text { April 1999, pp. 209-38. }\end{array}$ & Majumdar & \\
\hline $\begin{array}{l}\text { No. 63: How Taxing Is Corruption on } \\
\text { International Investors? }\end{array}$ & Shang-Jin Wei & February 1997 \\
\hline $\begin{array}{l}\text { No. 62: What Can We Learn from the } \\
\text { Experience of Transitional Economies with } \\
\text { Labour Market Policies? } \\
\text { No. 61: Published in: Accounting } \\
\text { Organizations and Society, "Economic } \\
\text { Transition, Strategy and the Evolution of } \\
\text { Management Accounting Practices: The Case } \\
\text { of India" 24(5,6), Jul/Aug 1999, pp. 379-412. }\end{array}$ & $\begin{array}{l}\text { Tito Boeri } \\
\text { Shannon W. Anderson and William N. } \\
\text { Lanen }\end{array}$ & $\begin{array}{l}1997 \\
\text { April } 1997\end{array}$ \\
\hline $\begin{array}{l}\text { No. 60a: Enterprise Investment During the } \\
\text { Transition: Evidence from Czech Panel Data }\end{array}$ & Lubomír Lizal and Jan Svejnar & December 1997 \\
\hline $\begin{array}{l}\text { No. 59: Published in: Journal of Law, } \\
\text { Economics, and Organization, "Institutional } \\
\text { Environment, Community Government, and } \\
\text { Corporate Governance: Understanding } \\
\text { China's Township-Village Enterprises." } \\
\text { 14(1), April 1998, pages 1-23 }\end{array}$ & Jiahua Che and Yingyi Qian & April 1997 \\
\hline $\begin{array}{l}\text { No. 58: From the Grabbing Hand to the } \\
\text { Helping Hand }\end{array}$ & Jiahua Che & June 2000 \\
\hline $\begin{array}{l}\text { No. 57: Published in: Brookings Papers on } \\
\text { Economic Activity, "The Unofficial Economy } \\
\text { in Transition." 1: 1998. }\end{array}$ & $\begin{array}{l}\text { Simon Johnson, Daniel Kaufmann, and } \\
\text { Andrei Schleifer }\end{array}$ & June 1997 \\
\hline $\begin{array}{l}\text { No. 56: Taxes and Government Incentives: } \\
\text { Eastern Europe vs. China }\end{array}$ & Roger H. Gordon and David D. Li & April 1997 \\
\hline No. 55: Corruption and Reform & Susanto Basu and David Li & June 1996 \\
\hline $\begin{array}{l}\text { No. 54: Decentralization and the } \\
\text { Macroeconomic Consequences of } \\
\text { Commitment to State-Owned Firms }\end{array}$ & Loren Brandt and Xiaodong Zhu & June 1997 \\
\hline $\begin{array}{l}\text { No. 53: Published in: The International } \\
\text { Journal of Industrial Organization, } \\
\text { "Competitive Shocks and Industrial Structure: } \\
\text { The Case of Polish Manufacturing." August, } \\
\text { 1999. . }\end{array}$ & Pankaj Ghemawat and Robert E. Kennedy & May 1997 \\
\hline $\begin{array}{l}\text { No. 52: Published in: The Quarterly Journal } \\
\text { of Economics, "Insecure Property Rights and } \\
\text { Government Ownership of Firms." May, } \\
\text { 1998. }\end{array}$ & Jiahua Che and Yingyi Qian & May 1997 \\
\hline $\begin{array}{l}\text { No. 51: Incentives, Scale Economies, and } \\
\text { Organizational Form }\end{array}$ & $\begin{array}{l}\text { Eric Maskin, Yingyi Qian, and Chenggang } \\
X u\end{array}$ & May 1997 \\
\hline $\begin{array}{l}\text { No. 50: Published in: Post-Soviet-Affairs, } \\
\text { "End of the Tunnel? The Effects of Financial } \\
\text { Stabilization in Russia" April-June 1997, } \\
\text { pages 105-33 }\end{array}$ & $\begin{array}{l}\text { Barry W. Ickes, Peter Murrell, and Randi } \\
\text { Ryterman }\end{array}$ & March 1997 \\
\hline $\begin{array}{l}\text { No. 49: The Evolution of Bank Credit Quality } \\
\text { in Transition: Theory and Evidence from } \\
\text { Romania }\end{array}$ & Enrico C. Perotti and Octavian Carare & October 1996 \\
\hline No. 48: Where Do the Leaders Trade? & Jan Hanousek and Libor Nemecek & May 1997 \\
\hline
\end{tabular}

Publications denoted by an asterisk are not available on the Kresge Library webpage (http://www.wdi.bus.umich.edu) 


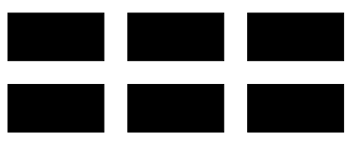

THE WILLIAM DAVIDSON INSTITUTE

AT THE UNIVERSITY OF MICHIGAN BUSINESSSCHOOL

\begin{tabular}{|c|c|c|}
\hline $\begin{array}{l}\text { Information Revelation and Interactions } \\
\text { Between the Segments of Czech Capital } \\
\text { Markets }\end{array}$ & & \\
\hline $\begin{array}{l}\text { No. 47: Firms' Heterogeneity in Transition: } \\
\text { Evidence from a Polish Panel Data Set }\end{array}$ & Irena Grosfeld and Jean-François Nivet & May 1997 \\
\hline $\begin{array}{l}\text { No. 46: Strategic Creditor Passivity, } \\
\text { Regulation, and Bank Bailouts }\end{array}$ & Janet Mitchell & May 1997 \\
\hline $\begin{array}{l}\text { No. 45a: Decentralization in Transition } \\
\text { Economies: A Tragedy of the Commons? }\end{array}$ & Daniel M. Berkowitz and Wei Li & September 1997 \\
\hline $\begin{array}{l}\text { No. 44a: The Information Content of Stock } \\
\text { Markets: Why do Emerging Markets have } \\
\text { Synchronous Stock Price Movements? } \\
\text { (forthcoming in the Journal of Financial } \\
\text { Economics). }\end{array}$ & $\begin{array}{l}\text { Randall Morck, Bernard Yeung, and } \\
\text { Wayne Yu }\end{array}$ & February 1999 \\
\hline $\begin{array}{l}\text { No. 43: Agency in Project Screening and } \\
\text { Termination Decisions: Why Is Good Money } \\
\text { Thrown After Bad? }\end{array}$ & Chong-en Bai and Yijiang Wang & May 1997 \\
\hline $\begin{array}{l}\text { No. 42: Published in: Economics of } \\
\text { Transition, "Channels of Redistribution: } \\
\text { Inequality and Poverty in the Russian } \\
\text { Transition." Vol. } 7 \text { (2) } 1999 .\end{array}$ & $\begin{array}{l}\text { Simon Commander, Andrei Tolstopiatenko, } \\
\text { and Ruslan Yemtsov }\end{array}$ & May 1997 \\
\hline $\begin{array}{l}\text { No. 41: Published in: Economics of } \\
\text { Transition, “Labour Market Characteristics } \\
\text { and Profitability: Econometric Analysis of } \\
\text { Hungarian Exporting Firms, 1986-1995” } \\
\text { 6(1), May 1998, pages 145-62 }\end{array}$ & László Halpern and Gabor Korosi & May 1997 \\
\hline $\begin{array}{l}\text { No. 40: Published in: the Harvard Law } \\
\text { Review, "The Tragedy of the Anticommons: } \\
\text { Property in the Transition from Marx to } \\
\text { Markets." January } 1998 .\end{array}$ & Michael Heller & February 1997 \\
\hline $\begin{array}{l}\text { No. 39: Privatization and Managerial } \\
\text { Efficiency }\end{array}$ & Olivier Debande and Guido Friebel & May 1997 \\
\hline $\begin{array}{l}\text { No. } 38 \text { Published in: The Quarterly Journal } \\
\text { of Economics, “Disorganization.” Vol. 112, } \\
\text { No. 4, November 1997, pp. 1091-1126. }\end{array}$ & Olivier Blanchard and Michael Kremer & January 1997 \\
\hline $\begin{array}{l}\text { No. 37: Published in: Economics of } \\
\text { Transition, "Transition and the Output Fall." } \\
\text { 7(1), 1999, pages 1-28. }\end{array}$ & Gérard Roland and Thierry Verdier & March 1997 \\
\hline $\begin{array}{l}\text { No. 36: Restructuring an Industry During } \\
\text { Transition: A Two-Period Model }\end{array}$ & Richard Ericson & September 1996 \\
\hline $\begin{array}{l}\text { No. 34: The East-West Joint Venture: BC } \\
\text { Torsion Case Study }\end{array}$ & Sonia Ferencikova and Vern Terpstra & December 1998 \\
\hline $\begin{array}{l}\text { No. } 33 \text { Published in: Journal of Comparative } \\
\text { Economics, "Quantifying Price Liberalization } \\
\text { in Russia." Vol. 26, No. 4, December 1998, } \\
\text { pp. } 735-737 .\end{array}$ & $\begin{array}{l}\text { Daniel Berkowitz, David DeJong, and } \\
\text { Steven Husted }\end{array}$ & December 1998 \\
\hline $\begin{array}{l}\text { No. 32: What Can North Korea Learn from } \\
\text { China's Market Reforms? }\end{array}$ & John McMillan & September 1996 \\
\hline $\begin{array}{l}\text { No. 31: Published in : China-Economic- } \\
\text { Review, "Towards a Model of China as a } \\
\text { Partially Reformed Developing Economy } \\
\text { Under a Semifederalist Government.", 9(1), }\end{array}$ & Yijiang Wang and Chun Chang & March 1997 \\
\hline
\end{tabular}

Publications denoted by an asterisk are not available on the Kresge Library webpage (http://www.wdi.bus.umich.edu) 


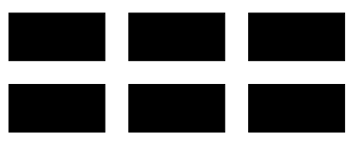

THE WILLIAM DAVIDSON INSTITUTE

AT THE UNIVERSITY OF MICHIGAN BUSINESSSCHOOL

\begin{tabular}{|c|c|c|}
\hline Spring 1998, pages 1-23. & & \\
\hline $\begin{array}{l}\text { No. 30: Convergence in Output in Transition } \\
\text { Economies: Central and Eastern Europe, } \\
\text { 1970-1995 }\end{array}$ & Saul Estrin and Giovanni Urga & February 1997 \\
\hline $\begin{array}{l}\text { No. 29: Published in: Economics of } \\
\text { Transition, "Altered Band and Exchange } \\
\text { Volatility." Volume 6, no. 1, 1998, 173-181. }\end{array}$ & Evzen Kocenda & March 1997 \\
\hline $\begin{array}{l}\text { No. 28: Published in: Quarterly Journal of } \\
\text { Economics, "Public Versus Private } \\
\text { Ownership of Firms: Evidence from Rural } \\
\text { China." Volume 113, no. 3, August 1998, 773- } \\
\text { 808. }\end{array}$ & Hehui Jin and Yingyi Qian & January 1997 \\
\hline $\begin{array}{l}\text { No. 27: East-West Joint Ventures in a } \\
\text { Transitional Economy: The Case of Slovakia }\end{array}$ & Sonia Ferencikova & March 1997 \\
\hline $\begin{array}{l}\text { No. 26: Published in Economic Analysis } \\
\text { "Behavior of a Slovenian Firm in Transition" } \\
\text { Vol. 1, no. 1, 1998, 57-73. }\end{array}$ & Janez Prasnikar & February 1997 \\
\hline $\begin{array}{l}\text { No. 25: Cultural Encounters and Claims to } \\
\text { Expertise in Postcommunist Capitalism }\end{array}$ & Michael D. Kennedy & February 1997 \\
\hline $\begin{array}{l}\text { No. 24: ZVU a.s.: Investment Funds on the } \\
\text { Board of Directors of an Engineering Giant }\end{array}$ & Tory Wolff & August 1995 \\
\hline $\begin{array}{l}\text { No. 23: The Role of Investment Funds in the } \\
\text { Czech Republic (joint publication with Czech } \\
\text { Management Center) }\end{array}$ & Dusan Triska & June 1996 \\
\hline $\begin{array}{l}\text { No. 22: Czech Investment Fund Industry: } \\
\text { Development and Behaviour (joint publication } \\
\text { with Czech Management Center) }\end{array}$ & Richard Podpiera & May 1996 \\
\hline $\begin{array}{l}\text { No. 21: Restructuring of Czech Firms: An } \\
\text { Example of Gama, a.s. (joint publication with } \\
\text { Czech Management Center) }\end{array}$ & Antonin Bulin & June 1996 \\
\hline $\begin{array}{l}\text { No. 20: YSE Funds: A Story of Czech } \\
\text { Investment Funds (joint publication with } \\
\text { Czech Management Center) }\end{array}$ & Michal Otradovec & November 1995 \\
\hline $\begin{array}{l}\text { No. 19: První Investicni a.s., The First } \\
\text { Investment Corporation (joint publication } \\
\text { with Czech Management Center) }\end{array}$ & Jaroslav Jirasek & August 1995 \\
\hline $\begin{array}{l}\text { No. 18: PPF a.s., The First Private Investment } \\
\text { Fund (joint publication with Czech } \\
\text { Management Center) }\end{array}$ & Michal Otradovec & November 1995 \\
\hline $\begin{array}{l}\text { No. } 17 \text { Published in: Post-Soviet Geography } \\
\text { and Economics, "Russia's Managers in } \\
\text { Transition: Pilferers or Paladins?" Vol. 37, } \\
\text { o.7 (September 1996), pp. 397-426. }\end{array}$ & Susan J. Linz and Gary Krueger & November 1996 \\
\hline $\begin{array}{l}\text { No. 16: Banks in Transition-Investment } \\
\text { Opportunities in Central Europe and Russia } \\
\text { Edited Transcript from } 31 \text { May } 1996 \\
\text { Conference in New York City }\end{array}$ & $\begin{array}{l}\text { With commentary and edited by Anna } \\
\text { Meyendorff }\end{array}$ & January 1997 \\
\hline $\begin{array}{l}\text { No. 15: Marketing in Transitional Economies: } \\
\text { Edited Transcript \& Papers from } 1 \text { April } 1996 \\
\text { Conference in Ann Arbor, Michigan }\end{array}$ & Compiled by The Davidson Institute & December 1996 \\
\hline $\begin{array}{l}\text { No. 14: Pensions in the Former Soviet Bloc: } \\
\text { Problems and Solutions. Published by }\end{array}$ & Jan Svejnar & November 1996 \\
\hline
\end{tabular}

Publications denoted by an asterisk are not available on the Kresge Library webpage (http://www.wdi.bus.umich.edu) 


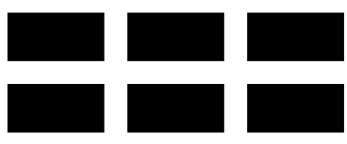

THE WILLIAM DAVIDSON INSTITUTE

AT THE UNIVERSITY OF MICHIGAN BUSINESSSCHOOL

\begin{tabular}{|c|c|c|}
\hline $\begin{array}{l}\text { Council on Foreign Relations. "The Coming } \\
\text { Global Pension Crisis" New York, } 1997\end{array}$ & & \\
\hline $\begin{array}{l}\text { No. 13: Enterprise Restructuring and } \\
\text { Performance in the Transition. Forthcoming } \\
\text { in Financial Systems in Transition: The } \\
\text { Design of Financial Systems in Central } \\
\text { Europe eds. Anna Meyendorff and Anjan } \\
\text { Thakor. }\end{array}$ & $\begin{array}{l}\text { Lubomir Lizal, Miroslav Singer, and Jan } \\
\text { Svejnar }\end{array}$ & December 1996 \\
\hline $\begin{array}{l}\text { No. } 12 \text { Published in: Journal of International } \\
\text { Marketing, "Executive Insights: Marketing } \\
\text { Issues and Challenges in Transitional } \\
\text { Economies." Vol. 5, No. 4, 1997, pp. 95-114. } \\
\text { Also published in: Marketing Issues in } \\
\text { Transitional Economies ed. Rajeev Batra. }\end{array}$ & Rajeev Batra & April 1997 \\
\hline $\begin{array}{l}\text { No. 11: Worker Trust and System } \\
\text { Vulnerability in the Transition from Socialism } \\
\text { to Capitalism }\end{array}$ & Andrew Schotter & August 1996 \\
\hline $\begin{array}{l}\text { No. } 10 \text { Published in: Comparative Economic } \\
\text { Studies, "Russian Firms in Transition: } \\
\text { Champions, Challengers, and Chaff." Vol. } \\
\text { 39, No.2, Summer 1997, pp. 1-36. }\end{array}$ & Susan J. Linz & July 1996 \\
\hline $\begin{array}{l}\text { No. 9: Corporate Debt Crisis and Bankruptcy } \\
\text { Law During the Transition: The Case of China }\end{array}$ & David D. Li and Shan Li & December 1995 \\
\hline $\begin{array}{l}\text { No. } 8 \text { Published in: Journal of Comparative } \\
\text { Economics, "A Theory of Ambiguous } \\
\text { Property Rights in Transition Economies: The } \\
\text { Case of the Chinese Non-State Sector." Vol. } \\
\text { 23, No. 1, August 1996, pp. 1-19. }\end{array}$ & David D. Li & June 1996 \\
\hline $\begin{array}{l}\text { No. 7: The Foreign Economic Contract Law of } \\
\text { China: Cases and Analysis }\end{array}$ & Dong-lai Li & June 1993 \\
\hline $\begin{array}{l}\text { No. 3: Bank Privatization in Hungary and the } \\
\text { Magyar Kulkereskedelmi Bank Transaction }\end{array}$ & Roger Kormendi and Karen Schnatterly & May 1996 \\
\hline $\begin{array}{l}\text { Replacing Nos. 1-2 \& 4-6: Journal of } \\
\text { Comparative Economics Symposium on } \\
\text { "Bank Privatization in Central Europe and } \\
\text { Russia." Vol. 25, No. 1, August } 1997 .\end{array}$ & $\begin{array}{l}\text { No. } 1 \text { "Bank Privatization in Transitional } \\
\text { Economies" by Roger Kormendi and } \\
\text { Edward Snyder. No. } 2 \text { "Transactional } \\
\text { Structures of Bank Privatizations in } \\
\text { Central Europe and Russia" by Anna } \\
\text { Meyendorff and Edward A. Snyder. No. } 4 \\
\text { "Bank Privatization in Poland: The Case } \\
\text { of Bank Slaski" by Jeffery Abarbaness and } \\
\text { John Bonin. No. } 5 \text { "Bank Privatization in } \\
\text { Post-Communist Russia: The Case of } \\
\text { Zhilsotsbank" by Jeffery Abarbanell and } \\
\text { Anna Meyendorff and No. } 6 \text { "”"The Czech } \\
\text { Republic's Commercial Bank: Komercni } \\
\text { Banka" by Edward A. Snyder and Roger } \\
\text { C. Kormendi. }\end{array}$ & August 1997 \\
\hline
\end{tabular}

Publications denoted by an asterisk are not available on the Kresge Library webpage (http://www.wdi.bus.umich.edu) 